\author{
Yu-Fen Huang ${ }^{1}$ \\ Chih-Chin Huang ${ }^{1}$ \\ Cho-Chun $\mathrm{Hu}^{2}$ \\ Huan-Tsung Chang ${ }^{1,2}$ \\ ${ }^{1}$ Department of Chemistry, \\ National Taiwan University, \\ Taipei, Taiwan \\ ${ }^{2}$ Department of Natural Science \\ Education, \\ National TaiTung University, \\ TaiTung, Taiwan
}

Received February 27, 2006

Revised May 14, 2006

Accepted May 15, 2006

\section{Review \\ Capillary electrophoresis-based separation techniques for the analysis of proteins}

\begin{abstract}
CE offers the advantages of high speed, great efficiency, as well as the requirement of minimum amounts of sample and buffer for the analysis of proteins. In this review, we summarize the CE-based techniques coupled with absorption, LIF, and MS detection systems for the analysis of proteins mostly within the past 5 years. The basic principle of each technique and its advantages and disadvantages for protein analysis are discussed in brief. Advanced CE techniques, including on-column concentration techniques and high-efficiency multidimensional separation techniques, for high-throughput protein profiling of complex biological samples and/or of single cells are emphasized. Although the developed techniques provide improved peak capacity, they have not become practical tools for proteomics, mainly because of poor reproducibility, lowsample lading capacity, and low throughput due to ineffective interfaces between two separation dimensions and that between separation and MS systems. In order to identify the complexities and dynamics of the proteomes expressed by cells, tissues, or organisms, techniques providing improved analytical sensitivity, throughput, and dynamic ranges are still demanded*.
\end{abstract}

Keywords: Capillary electrophoresis / Multidimensional separation / Stacking DOI 10.1002/elps.200600100

\section{Introduction}

Proteomics focuses on the fundamental understanding of complex biological processes, including cell development, cell differentiation, and signal transduction. It has become one of the most important and growing research fields after the so-called postgenomic era. Unlike the static genome, proteome is a dynamic expression of the entire set of proteins from a cell or a tissue [1]. Proteomes are also highly divergent among different cells or tissues. The variations of proteomes

Correspondence: Professor Huan-Tsung Chang, Department of Chemistry, National Taiwan University, 1, Section 4, Roosevelt Road, Taipei 106, Taiwan

E-mail: changht@ntu.edu.tw

Fax: $+886-2-33661171$

Abbreviations: BGTP $\gamma \mathbf{S}$, BODIPY FL GTP $\gamma$ S; CA, carbonic anhydrase; CPA, cross-linked polyacrylamide; CRPLC, capillary RPLC; CSF, cerebrospinal fluids; ERK, extracellular signal-regulated kinase; Fab, antigen-binding fragments; FTICR, Fourier-transform ion cyclotron resonance; Hb, hemoglobin; IACE, immunoaffinity CE; NECEEM, nonequilibrium CE of the equilibrium mixture; OT, opentubular; PEO, poly(ethylene oxide); SEC, size-exclusion chromatography; SPME, solid-phase microextraction; tCITP, transient CITP; WCID, whole-column imaging detection generally involve the coordinated expressions and interactions of multiple genes and proteins in synergistic efforts. Therefore, detection, identification, and quantification of the multiple proteins constitutions, determination of their interactions and localizations within the cell, and characterization of their post-translational modifications are essential toward understanding the regulation of biological systems.

When parts of the biological systems are perturbed by, for example, chemicals and stress, malfunctions or misfunctions that contribute to or cause disease may arise. The detrimental events can be understood by discovering proteins distinctive from the normal to abnormal physiological processes. Finding proteins (biomarkers) that play key roles in the development of malfunctions or misfunctions of cells or tissues is also helpful for early detection and diagnosis of diseases [2] as well as for searching new targets for development of new drugs [3, 4]. In cells or tissues, there are usually a large number of proteins that vary widely in their physicochemical properties including molecular weight (MW), pl, solubility,

* This paper is dedicated to the memory of a great mentor of H. T. Chang, Andreas Chrambach. 
acidity/basicity, and hydrophobicity/hydrophilicity. Moreover, the protein concentrations can extend over 6 orders of magnitude and it is often the trace proteins that are of greatest interest in systems biology [5]. For these reasons, there are continuing needs to develop and evaluate new platforms for protein analysis [6-12].

2-D PAGE is one of the most powerful methods for protein analysis [13-15]. A typical 2-D PAGE system consists of IEF as the first dimension and sieving as the second dimension in which SDS is often used. It is usually easy to resolve $>1000$ proteins in a single 2-D-PAGE run. After staining by using reagents such as $\mathrm{CBB}$ or silver ions and then destaining in acidic aqueous solution containing organic solvent-like methanol, spots of interest are excised and then subjected to proteolytic digestion. The peptides are then analyzed by MALDI-MS, and database searches are carried out to identify the proteins [16]. Throughput of 2-D PAGE for protein analysis is hindered, mainly because of slow separation, tedious staining and destaining processes, and difficulties of fabricating highly compatible interfaces to MS instruments [17]. Although silver staining provides the sensitivity for $0.1-10-n g$ amounts of proteins, which corresponds to 20-200 fmol for a 50-kDa protein, the dynamic ranges of proteins are at best $10^{4}$ that make it difficult for simultaneous determination of low- and high-abundance proteins. In addition, 2-D PAGE-MS techniques are not easy for automation and thus are usually operated by experienced researchers.

Since the electrophoretic separation of fluorescent derivatives of amino acids, dipeptides, and amines in a capillary format was demonstrated in 1981 [18], CE has become a powerful separation technique for proteins. Having the advantages of high speed, excellent resolving power, sensitivity, requirement for minute quantity of samples and reagents, and ease of automation, the potential of CE for proteomics has been recognized [1924]. Despite those advantages, the complexities of biological samples, the microheterogeneities of proteins, and the abundances of proteins greater than 6 orders of magnitude give great challenges of $\mathrm{CE}$ for achieving comprehensive and high-degree proteome coverage. To achieve that goal, preconcentration of proteins of interest by SPE prior to CE analysis has been suggested. In addition, multidimensional separation techniques are useful to improve peak capacity (the maximum number of separated peaks that can be filled to the space) according to the separation model proposed by Giddings [25]. For example, liquid-based multidimensional separation techniques such as 2-D HPLC, HPLC-CE, and CE-CE formats have been demonstrated useful for proteomics [26-33].
Owing to the importance and popularity of CE-based techniques for protein analysis and proteomics, there have been more than 900 papers published in the past 3 years. Thus it is impossible to cover all of the work in this review. Readers who are interested in CE techniques for protein analysis may also refer to several excellent reviewed articles that have been frequently published in Analytical Chemistry, Electrophoresis, and Journal of Chromatography $A$ [19-22, 34-36]. In this review, we focus on recent advances in capillary-based separations of complex protein mixtures, including CE and CE-based multidimensional separation techniques. We particularly emphasize the basic concepts and potentials of newly developed CE-based techniques for protein analysis. Online concentration and solid-phase microextraction (SPME) techniques for improved sensitivity of proteins of interest are discussed in more detail. Recent CE-based multidimensional separation techniques that provide extremely high resolving power for selective proteins are highlighted. Examples of some recent CE-based techniques that provide protein profiles toward biomarker discovery and clinical diagnosis are provided to support their important roles in proteomics.

\section{Separation mechanisms and detection methods}

The separations of proteins in CE are mainly based on their charge-to-mass ratios, sizes (sieving), interactions with ligands (affinity), and/or hydrophobicity/hydrophilicity (partition). Zone electrophoresis, IEF, and ITP in capillary formats are often applied to the separations of proteins that have different migration mobilities in aqueous BGEs. The $\mathrm{pH}$ and ionic strength of the BGE are two most important parameters for determining separation speed and resolution of proteins because they affect their migration mobilities (charge densities). IEF is usually used to obtain the $\mathrm{p} /$ values of proteins. In order to suppress protein adsorption and variation of EOF, polymer solution such as hydroxylcellulose is often used to coat the capillary wall. A capillary filled with a gel or a polymer solution (prepared from a linear polymer) is generally utilized for separating proteins based on the sieving mechanism. To minimize the charge dependence of the mobility of proteins, shorten their separation time, and/or increase their solubility, SDS is often used to denature proteins prior to analysis and is added to the gel or polymer solution. Because the separation is dependent on the size of proteins in the presence of excess amounts of SDS, the linear plot of the mobility against the log MW of standard proteins is often used to estimate the MW values of unknown proteins [37]. In ACE, ligands (e.g., dyes, substrates, antibodies, and antigens) are either added to BGEs or immo- 
bilized on the capillary wall directly or through stationary phases such as polymers and particles to improve protein separation on the basis of different binding abilities of the ligands to proteins. MEKC and CEC are two alternative methods for the separation of proteins, which are based on partition of proteins in mobile phase and (pseudo) stationary phase [19, 36, 38-43]. In CEC, a capillary is filled with particles or monoliths that have suitable sizes of pores and functional groups for highly efficient separation of proteins.

UV-Vis absorption at $280 \mathrm{~nm}$ is the most common detection mode for protein analysis; however, it is not as sensitive as LIF. Commonly used lasers in CE-LIF include $\mathrm{KrF}$ excimer laser at $248 \mathrm{~nm}, \mathrm{Nd} / \mathrm{YAG}$ laser at $266 \mathrm{~nm}, \mathrm{Ar}^{+}$ lasers at 275, 488, and/or $514 \mathrm{~nm}$, and He-Cd lasers at 320 and $442 \mathrm{~nm}$, violet diode lasers at 375 and $405 \mathrm{~nm}$, $\mathrm{He}-\mathrm{Ne}$ lasers at 543.6, 592.6, and $633 \mathrm{~nm}$ [44]. One drawback of LIF is its selectivity; only proteins containing tryptophan, tyrosine, and/or phenylalanine residues possess native fluorescence. Thus, derivitization of proteins with reagents (no or weak fluorescence background) to form protein derivatives that are highly fluorescent and stable is usually required when conducting CE-LIF. There are a number of commercially available reagents for labeling proteins, including fluorophores such as Alexa Fluor families, cyanine, 9-diethylamino-5H-benzo[a]phenoxazine-5-one, rhodamine, and SYPRO Red, as well as nonfluorescent ones such as albumin blue 580 . These dyes can be either covalently or noncovalently bound to proteins [45]. Another sensitive detection method for proteins in CE is MS that also allows determination of the MW values and sequences of proteins. Since its introduction in 1987 by Olivares et al. [46], CE coupled to MS has gained increasing acceptance in life sciences [4752]. In addition to its high price and less sensitivity when compared with CE-LIF, a sophisticated interface between $\mathrm{CE}$ and $\mathrm{MS}$ is usually required. Among different coupling interfaces used in CE-MS, sheath flow ESI sources are the most popular, whereby the sheath liquid circumflows the end of the capillary, closes the electrical circuit, and provides a constant flow rate. By using a supplemental fluid, the system stability improves and the requirement for the BGE to be compatible with ESI-MS is lessened. Although the LODs at an $\mathrm{S} / \mathrm{N}=3$ for proteins by CE-MS are mostly in the high attomole range $[53,54]$, a difference between BGE and supplemental fluid that is used to couple with low EOF rates results in a moving ionic boundary that complicates the separation process and causes poor reproducibility. Sample is also diluted when using a sheath liquid but to a lesser extent than expected, probably due to incomplete mixing in the Taylor cone. To overcome those shortages, ESI interfaces without supplemental fluids have been developed [55]. In addition to
ESI-MS, MALDI-MS is used in CE for protein analysis [56]. One advantage of MALDI-MS is that in many cases the protein samples can be used for further characterization. When compared to ESI, MALDI provides smaller dynamic ranges for proteins. Most reported $C E$ in conjunction with MALDI-MS techniques have off-line interfaces, where CE eluates are collected and then mixed with MALDI matrix before being transferred to MS analysis [57-59]. To accelerate analysis speed, online CE and MALDI-MS interfaces have been developed $[60,61]$. In one of the online CE and MALDI-MS systems, the separation capillary is terminated in a liquid junction, which allows the addition of MALDI matrix. The eluates and matrix pass from the liquid junction through a transfer capillary and are deposited onto a Mylar tape in which proteins are subjected to ionization prior to MS analysis [61].

\section{$3 \mathrm{CE}$}

\subsection{Capillary coating}

Suppression of protein adsorption onto the capillary wall ensures high efficiency and reproducibility for protein separation by CE $[62,63]$. There are two common methods to the deactivation of the capillary wall, which are static and dynamic coatings. In static coating, chemicals or polymers are used to coat the capillary through covalent bonding [64]. By applying this approach, capillary wall can be either modified to possess positive or negative charges $[65,66]$ or neutral [67-70]. Use of silane bifunctional reagents [71], Grignard chemistry [72], and thermal immobilization [73] are common for polymer attachment. One example is to form a cross-linked polyacrylamide (CPA) by chemically linking the linear polyacrylamide molecules around the rims of the cavities (microspots) in which the silica surfaces are poorly coated [74]. Compared to capillaries coated with commercially available linear PA and hydroxypropylcellulose for CIEF, capillaries coated with CPA are much more stable and robust. For example, the CPA capillary provides high efficiency and reproducibility for the separation of proteins (bovine pancreas, skeletal muscle myoglobin, and soybeans trypsin inhibitor) by CIEF. After several weeks of testing (80 runs), the separation efficiency remains virtually the same. Recently, CPA coating capillary-based "one-sample-two-separation" schemes have been developed; one separation takes care of the positively charged proteins and the other separation handles the negatively charged proteins [75]. Apparently, this approach has reduced sample throughput. To compensate and further enhance the throughput, a multiplexed CZE system was built and utilized to allow two separations to be performed simultaneously. An eight-lane CZE 
system with UV detection was applied to show the feasibility of this approach for high-resolution separation and comprehensive profiling of proteins in M10 cell extracted samples.

Static coating is stable at $\mathrm{pH} 3.0-10.0$, but it usually requires tedious coating processes. In recent years, dynamic coating of the capillary wall with chemicals or polymers has become more popular, mainly because it is simple and allows regeneration of fresh capillary wall after each run by simply flushing the chemicals or polymers through capillaries. Chemicals and polymers that provide selfcoating capability are usually used in dynamic coating. Chemicals such as amines and surfactants have been tested with different degrees of success [76-80], including phospholipids 1,2-dilauroyl-sn-phosphatidylcholine [81, 82] and didodecyldimethylammonium bromide [83]. Common polymers that are used to suppress protein adsorption and EOF include celluloses [84], dextran [85], PA [86, 87], poly(vinyl alcohol) [88, 89], PVP [90-92], and poly(ethylene oxide) (PEO) [93]. New dynamic coating materials such as EOTrol and UltraTrol have proved to be useful for the separation of protein isoforms by CZE [94]. The coatings allow reproducible EOF modulation in the cathodal direction to a level of $10^{-9} \mathrm{~m}^{2} \mathrm{~V}^{-1} \mathrm{~s}^{-1}$. Under nondenaturing conditions, CE using the deactivated capillaries allows separation of the isoforms of BSA, $\alpha_{1}$-antitrypsin, and transferrin, with high reproducibility both in peak areas and apparent mobility.

When using surfactants to suppress protein adsorption, EOF is often existent in the system. Thus, a particular attention has to be paid to minimize the variation of EOF during separation. In addition, surfactants may cause interferences in the fluorescence and MS signals of proteins. To minimize the problems, protein separation is often conducted in the absence of EOF by using capillaries coated and filled with polymers. In addition to sieving capability, polymer solutions usually do not cause denaturation of proteins and provide less MS interference mainly because neutral polymers do not enter the MS system in the absence of EOF [95-98]. However, the separation is possibly slower as a result of minimum EOF. In addition, preparation of polymer solutions and filling high viscous polymer solution to small sizes of capillaries are not as easy as use of surfactants.

\subsection{Zone electrophoresis}

CZE is known for its high separation efficiency, fast analysis time, and simple setup with a low risk of loosing analytes. Thus, it has frequently been used for peptide and proteins analysis [99, 100]. The practicality of CZE has been demonstrated, including detecting monoclonal components in serum samples [101], quantitation of insulin derivates in urine, serum, and plasma samples [102], quantitation of HSA in serum plasma [103], and analyses of polypeptides in dialysis fluids [104] as well as in plasma ultrafiltrates [105]. CZE with UV detection has been applied to determination of albumin, $\alpha_{1}$-antitrypsin, $\alpha_{1}$-acid glycoprotein, haptoglobin, fibrinogen, IgA, IgG, and IgM in human plasma from 200 patients [106]. With the exception of fibrinogen, a good correlation between $\mathrm{CE}$ and immunonephelometry has been achieved for the determination of the proteins $\left(R^{2}=0.883-0.913\right)$. CE with UV detection is useful for studying the degree of phosphorylation of three substrates MBP peptides (MBP1, KNIVTPRTPPPSQGK; MBP2, VPRTPGGRR; and MBP3, APRTPGGRR) by using extracellular signal-regulated kinase (ERK) [107]. ERK, which is one of the mitogenactivated protein kinase families, is a key regulatory enzyme mediating cell responses to mitogenic stimulation and is activated in response to peptide growth factors. Activated ERK plays an important role in many signal transduction pathways through phosphorylation of numerous substrates including MBP, microtubule-associated protein 2, and nuclear protein. The results show that MBP3 peptide is the most efficient substrate for phosphorylation reaction by ERK, which is in an excellent agreement with that obtained by MALDI-TOF-MS measurements. When compared to conventional enzyme assays, this developed CE method is relatively rapid, easy, and safe. CE with LIF detection was tested for the determination of hENT1 (a major mediator of cellular entry of nucleosides and anticancer nucleoside drugs) in cells using 5-SAENTA-x8f dye that binds to hENT1 protein with high affinity and specificity [108]. Accuracy was evaluated by comparing the CE results with those obtained by flow cytometry, with a good correlation $(r=0.96)$. The RSD of the hENT1 assay for nine independent assays of the same cell line was $10 \%$, which is three times superior to results obtained by conducting a flow cytometric assay. CZE with LIF detection shows the feature for comparing the biocatalytic activities of trypsin bound to gold nanoparticles and trypsin for digestion of proteins [109]. By comparing the electropherograms, the loss in the bioactivity of trypsin that was bound to gold nanoparticles was found.

Online coupling of CE with ESI-TOF-MS is useful to obtain patterns of peptides and proteins present in the urine of healthy human individuals [110]. The results lead to the establishment of a normal urine polypeptide pattern, consisting of 247 polypeptides, each of which was found in more than $50 \%$ of healthy individuals. Applying the CEMS method to the analysis of urine samples of patients with kidney disease reveals differences in polypeptide patterns from those of healthy people. CE-MS was also 
applied to the analysis of urine samples from patients suffering from membranous glomerulonephritis and healthy volunteers, with identification of approximately 200 potential polypeptide biomarkers [111]. The same method was further applied to the analysis of urine samples from patients who had undergone allogeneic hematopoietic stem cell transplantation [112]. More than 1000 different polypeptides could be detected in individual samples. Polypeptide patterns excreted in the urine samples of the patients are significantly different from those of healthy volunteers. The merit of CE-ESI-MS for protein analysis is strongly reflected in obtaining the subcellular proteomics of ribosomal Escherichia coli [113]. By using only $3.4 \mathrm{ng}$ of ribosomal proteins, 55 out of the 56 ribosomal proteins were detected without any difficulty. The power of CE is further supported by its capability for the characterization of post-translational modification (amidation, alkylation, glycosylation, and (de)phosphrylation) of proteins that is critical to protein function and dysfunction [114]. Using green fluorescent protein and CE-LIF, monitoring the phosphorylation and translocation of the ERK2 proteins after stimulation of PC 12 cells by a mitogen (treating with nerve growth factor) [115] has been demonstrated. The results show the presence of the nonphosphorylated green fluorescent protein-ERK2 at $6.7 \mathrm{~min}$ and phosphorylated green fluorescent protein-ERK2 at 5.3-5.5 min in cell lysates. The results are in good agreements with those obtained from confocal laser scanning microscope imaging and Western blot measurements.

\subsection{IEF}

CIEF is one of the separation techniques that provide extremely high resolving power. Since the first experiments performed by Hjertén and co-workers in the mid-1980s $[116,117]$, CIEF has become popular for protein analysis. CIEF peak capacities of up to several hundreds are realistic for intact proteins, showing that it is one of the most powerful single-dimensional separation techniques for proteins [118]. Analysis of hemoglobin $(\mathrm{Hb})$ and globin chain compositions of human blood is important in the diagnosis and management of congenital hemoglobinopathies and thalassemias. A two-step CIEF with UV detection in conjunction with pressure mobilization has been developed for the analysis of $\mathrm{Hb}$ variants [119]. The migration ratio of proteins to carbonic anhydrase (CA) I for $\mathrm{Hb} A_{0}$ in normal human blood is $0.877 \pm 0.004$, and those of the $\alpha$ - and $\beta$-globin chains are $0.673 \pm 0.004$ and $0.847 \pm 0.005$, respectively. The ratios of peak heights between the $\beta$ - and $\alpha$-globin chains $(\beta / \alpha)$ in the normal $\mathrm{Hbs}$ obtained from four subjects are almost constant at $2.5 \pm 1$. With its extremely high resolving power, CIEF is advantageous for the determination of the $\mathrm{pl}$ values of antibody and $\mathrm{Hb}$ variants [120-124]. The $\mathrm{pl}$ of $\mathrm{Hb} \mathrm{C}$ determined by CIEF is significantly different from those of $\mathrm{Hb}$ E, C-Harlem, and O-Arab [120]. The result shows that $\mathrm{p} /$ is an objective and specific criterion of $\mathrm{Hb}$ variants identification. Having its great resolving power, the separation of $\mathrm{Hb}$ Koln, M-Saskatoon, Aida, S/Aida hybrid, and common $\mathrm{Hb}$ variants is realistic by CIEF. This report successfully demonstrated that CIEF exhibits both diagnostic sensitivity and specificity.

CIEF with UV detection is powerful for the determination of charged microheterogeneity of proteins in cerebrospinal fluids (CSFs) of patients with various neurological disorders. One representative is to identify at least four isoforms of $\beta$-trace protein (lipocalin-type prostaglandin $D$ synthase) [125]. In order to achieve high efficiency and reproducibility, deactivated silica capillaries are often used in CIEF [45]. Owing to extremely high resolving power (about 70 peaks and shoulders of CSF proteins are resolved), CIEF is efficient for the analysis of proteins in CSF and serum samples [126]. The study suggests that the pathological changes in the CSF proteins from patients with various neurological disorders occur, while the serum proteins have no significant difference from those of healthy people. A CIEF with a double sector MS system was built and used for direct analyses of CSF and whole blood samples from neurological disorder and diabetic patients [127, 128]. The results show that glycated $\alpha$ - and $\beta$-chains of $\mathrm{Hb}$ are found to be in almost equal abundance in diabetic-patient blood. An on-target-fraction collection using a sheath liquid flow around the separation capillary was fabricated for the off-line coupling of CIEF with MALDI-MS that were used for the analysis of a mixture of four standard proteins [129]. The influence of the carrier ampholytes even at a concentration of $5 \%$ on the protein MALDI spectra is negligible in the CIEF step. The use of a sheath flow rate of $1 \mu \mathrm{L} / \mathrm{min}$ results in limited dilution, and thus an LOD for CA II is $172 \mathrm{fmol}$. Another approach was further employed for the analysis of human blood serum, suggesting that off-line coupling of CIEF with MALDI-TOF-MS is a promising technique for the analysis of complex biological samples [130]. The method provides similar protein $\mathrm{pl}$ and mass values to those obtained by conducting 2-D PAGE with MALDI-TOF-MS, while it is faster, simpler, and greater capability for automation. The method requires only small sample volumes $(100 \mathrm{~nL})$ and no special efforts for high resolution of proteins having sizes in high and low mass ranges.

The power of CIEF is further supported by highly efficient analysis of recombinant, mAb [123, 124, 131, 132]. Affinity-probe CIEF with LIF detection is practical for the analysis of human $\alpha_{1}$-antitrypsin [133]. Prior to analysis, a 
recombinant antigen-binding fragments (Fab') of mouse IgG1 against human $\alpha_{1}$-antitrypsin is labeled with tetramethylrhodamine on the single cysteine residue at the hinge region. The free form of human $\alpha 1$-antitrypsin and its complex with recombinant Fab'-tetramethylrhodamine derivatives are then separated by CIEF. The system provides an almost linear fluorescence signal response to standard samples of $\alpha_{1}$-antitrypsin over a concentration range of $5-1000 \mathrm{ng} / \mathrm{mL}$, with an LOD of around $2 \mathrm{ng} / \mathrm{mL}$. The concentration of $\alpha_{1}$-antitrypsin in a serum sample was determined to be $1.2 \mathrm{mg} / \mathrm{mL}$ by using this system. An imaging CIEF system was built and used for the determination of the identity, stability, and isoform distribution of a murine mAb [134]. The results suggest that the CIEF system is useful for $\mathrm{p} /$ profiling of proteins and for monitoring structural changes during the manufacturing processes and upon storage under a quality control environment.

With the advantages of high resolution, sensitivity, and capability for structure identification, CIEF with MS detection is powerful for the analysis of proteins in complicated biological samples [135-142]. One representative system was developed in a configuration of a combination of CIEF and Fourier-transform ion cyclotron resonance (FTICR)-MS that provides detailed information for complex protein mixtures, i.e., the $\mathrm{pl}$ and the mass values of the proteins with excellent resolution. CIEF-FTICR-MS provides the accurate $\mathrm{p} /$ values and masses of 1000 proteins in a cell lysate and structural information on 10000 tryptic peptides from the lysate in a single run, indicating that it is a high-throughput and sensitive method for proteomics [139]. Accurate mass measurements and partial amino acid content information are useful to unambiguously identify intact proteins from $E$. coli and Saccharomyces cerevisiae [143]. The proteins were extracted from the organisms grown in two minimal media with/without containing isotopically labeled leucine (LeuD10). The two protein extracts were mixed and analyzed by CIEF-FTICR-MS. The identities of proteins were further confirmed by repeating CIEF-FTICR measurements with samples that contain other isotopically labeled amino acid residues (e.g., His, Arg, lle, Phe, and Lys). The mass differences between the predicted and the experimental mass measurements provide insights into the nature of simple post-translational modifications. The results suggest that CIEF-FTICR-MS holds a great potential for proteomics.

\subsection{Sieving}

The pioneer works of CGE for protein analysis were separately published in the 1980s by Hjertén's [144] and Karger's [145] groups. Since then, it has become more and more evident that almost every method developed in slab GE can easily be transferred to a capillary format, with the advantages of rapidity, high resolution, and full automation with online data acquisition and data storage capability. Recently, polymer solutions that are prepared from linear polymers such as linear PA [146], dextran [147], PEO [148], pullulan [149], and hydroxypropylcellulose [150] are more commonly used in CE for protein separation based on the sieving mechanism. Compared to gel matrices, polymer solutions provide the advantages of low viscosity, ease of preparation, flexibility, and self-adsorption (dynamic coating) capability. Owing to their self-adsorption capability, the separation of proteins in CE using polymer solutions is commonly conducted in the absence of EOF. Like in SDSPAGE, SDS is commonly added to polymer solutions to improve resolution and solubility of proteins [151-153]. It has been reported that SDS binds to the proteins proportionally to their MW [154] and the charges of the complexes are mainly determined by the bound amount of negatively charged SDS molecules. Thus the electrophoretic mobilities of proteins are inversely proportional to their MWs in a polymer solution. As a result, large proteins migrate more slowly than small ones and the size of proteins can be determined by a Ferguson plot. Replaceable CPA solution that is easily filled by pressure means (80 psi) provides high-resolution separation of proteins having a wide size range over $\sim 4$ to $\sim 300 \mathrm{kDa}$ in the presence of SDS [153]. By using CPA at an optimized concentration ( $4 \%$ Tand $0.4 \% \mathrm{C}$ ), identification of 40 protein peaks from a crude $E$. coli cell extract sample is realistic.

In 2000, Tseng and Chang [155] demonstrated protein separation in the presence of EOF using PEO solution. In the presence of EOF, PEO solution enters from the anodic end to the capillary that is filled with Tris-borate buffer prior to analysis. This approach prevents a difficulty of filling polymer solutions by mechanical means such as pressure. Owing to selfadsorption of PEO, protein adsorption on the capillary wall is suppressed, which allows the separation of basic proteins like trypsinogen from acidic proteins like BSA [156]. A segmental-filling technique was carried out to improve the separation efficiency and to achieve high sensitivity for the analysis of proteins by CE-LIF. In order to minimize fluorescence quenching of proteins by SDS and control the interactions between proteins and SDS molecules, an SDS plug was applied prior to sample injection. By carefully controlling the concentration and length of the SDS plug, the analyses of several microheterogeneous proteins were achieved. Without any sample pretreatment, using a 10-s $1 \times$ SDS plug, six $\alpha$-amylase isoforms in a salivary sample were resolved in $17 \mathrm{~min}$ and three more peaks detected in a CSF sample, separately. The result shows the potential of this method for proteomics. 


\subsection{Partition}

Since the first report on CEC was published in 1974 [157], the high separation efficiency of CEC has been recognized in the separation society $[158,159]$. Proteins possess various charges and hydrophobic characteristics at different $\mathrm{pH}$ values, and thus they can be effectively resolved by CEC using packed beds, monolithics, and open-tubular (OT) stationary phases [160-162]. Differences in their charge to volume ratios allow proteins to be separated electrokinetically. In addition, the interactions of proteins with the stationary phase through ionic and/or hydrophobic bonding provide another separation force. Packed beds using microporous particles, frequently made of silica, are still the packing material of choice for many researchers in CEC $[163,164]$. It offers the advantage of availability of a variety of stationary phases developed for HPLC. However, frits that are not easily fabricated inside the capillary are usually required to prevent the loss of the stationary phase in capillaries. The first example that shows how CEC might evolve as a valuable alternative to micro-HPLC in the separation of complex samples and establish itself as a complementary technique in proteomics and peptidomics was demonstrated by Lubman and co-workers [165]. Using pressurized gradient elution CEC coupled with an IT storage/ reflectron TOF-MS system, separation of more than 20 peaks tryptic digest of bovine chicken ovalbumin was achieved within $17 \mathrm{~min}$. By taking the advantages of hydrophilic interactions and cationic exchanges of CEC stationary phase with solutes, five different di- and tripeptides were separated [166]. CEC coupled with ESIMS using a 3- $\mu \mathrm{m}$ ODS bed is useful for protein analysis $[167,168]$. Online concentration by taking the advantages of field-enhanced sample-stacking and chromatographic zone-sharpening effects is effective to improve up to 100fold sensitivities for cytochrome $c$, lysozyme, and insulin.

Monolithic stationary phase is advantageous over particle stationary phase, including high permeability, easy generation of EOF, convenient surface modification, and stability. Monoliths are easily created in situ from a wide variety of monomers such as lauryl methacrylate and ethylene dimethacrylate in the presence of cross-linkers and porogenic solvents $[169,170]$. The first example of monolithic CEC was tested for the separation of peptides in 1997 by Palm and Novotny [171]. Five small peptides were separated within $5 \mathrm{~min}$ in baseline using a PA/PEG monolith under isocratic elution. The first example of protein separation by CEC using a monolithic column was published by Ericson and Hjertén [172], where a stearyl methacrylate-based polymer containing both $\mathrm{C} 18$ groups and quaternary ammonium functions was used. CEC using a monolithic made from vinylbenzyl chloride and ethylene glycol dimethacrylate has the feature for the separation of a tryptic digest of cytochrome $c$ [173]. Using $1.6 \% \mathrm{w} / \mathrm{w} \quad$ [2-(acryloyloxy)ethyl] trimethyl ammonium methyl sulfate in the presence of ternary porogenic solvents [174], a variety of monoliths containing a cationic $\mathrm{C}_{17}$ residue were prepared and successfully used for the separation of two crude extracts of membrane proteins (galactosyl transferase and cytochrome $c$ reductase) that are highly hydrophobic. In each case, both the extracts of galactosyl transferase and cytochrome $c$ reductase were resolved into several single components within less than 5 min. A CEC column of poly(vinylbenzyl chloride-ethylene dimethacrylate) having a positively charged polymer on the capillary inner wall for annular EOF generation and an in situ-polymerized neutral bulk monolithic stationary phase provides high resolving power for the separation of peptides [175]. The results suggest that a mixed mode of RP chromatographic and electrophoretic migration mechanisms is responsible for high resolution.

OT-CEC offers several distinct advantages, including eliminations of use of the frits, bubble formation, and difficulties associated with packing stationary phases into capillaries [176]. In OT-CEC, the stationary phase is either coated or bonded to the inner walls of the capillary column to provide separation capability for proteins through interactions such as hydrophobic interaction, hydrogen bonding, and Coulombic attraction [176]. The limited loading capacity of OT-CEC columns due to their low phase ratio has been improved by etching the inner wall of the capillaries to increase the surface area [177-179]. This also leads to increased retention and improved resolution when compared to unetched capillaries. G-quartet DNA stationary phases in OT-CEC is effective for the separation of bovine milk proteins [107]. G-quartet DNA is an aptamer that has a natural tendency to undergoing weak and nondenaturing interactions with amino-based structures such as peptides and proteins. DNA/RNA molecules that have specific interactions with solutes such as proteins and small organic compounds are called aptamers that can be selected from random pools based on their binding ability to ligands. CEC using a 4-plane, G-quartet aptamer stationary phase and Tris-buffer allows baseline resolution of two $\beta$-lactoglobulin variants ( $A$ and $B$ ) that differ only in two amino acid residues in their sequences. The G-aptamer stationary phase has been proved to be useful for the separations of both purified milk proteins (both casein and whey proteins) as well as bovine skim milk in CEC [180].

\subsection{Affinity}

A comprehensive assignment and characterization of the interactions among proteins, polypeptides (functional proteomics), and other classes of biomolecules in a given 
organism is essential for system biology. High-capacity screening methods such as protein arrays and DNA arrays are good for ligand captures and interaction screening, but a detailed dynamic characterization of molecular interactions under physiological conditions is currently provided only by ACE [181-184]. The development of ACE centers on miniaturized immunoassays (labon-a-chip) for simple, fast, and sensitive measurements in clinical settings. Antigen-antibody and enzyme-substrate interactions form the basis of ACE to be the most specific and sensitive assays for analytes of interest in biofluids. In order to tailor-make antibodies for specific applications, ACE focuses on the in-depth characterization of immunoreagents with respect to reactivity and binding strength. An important issue in the miniaturization of immunoassays is to achieve great sensitivity comparable to that of traditional ELISAs that provide the advantages of sensitivity (subpicomolar detection limits) and highthroughput but they usually involve tedious processes.

Sensitive and selective immunoaffinity CE (IACE) techniques for proteomics have recently been reviewed [35]. IACE requires several important operational steps. The sample is introduced into the capillary and the target analyte(s) are selectively captured by one or more affinity ligand(s) that act as the analyte concentrator(s). Washing and cleanup processes are then applied to remove unbounded samples as well as nonspecifically bounded materials. Finally, the separation and detection in capillaries using suitable BGEs are conducted. Several applications of IACE have been described for quantifying $\lg E$, cardiac troponin I, cyclosporin A, neurotensin, angiotensin II, metenkephalin, cholecystokinin, gonadotropinreleasing hormone, and various cytokines in simple and complex matrixes [185-190]. With great stacking efficiencies, at least 100-10000-fold of sensitivity improvements, IACE allows quantification of the analytes at the concentrations greater than $1 \mathrm{ng} / \mathrm{mL}$ and $1 \mathrm{pg} / \mathrm{mL}$ with UV-absorbance detection and LIF detection, respectively.

ACE with LIF is sensitive and selective for the analysis of antibodies when using a fluorophore-labeled monomeric Fab from the erythropoietin specific antibody 5F12 [191]. Monomeric Fab was obtained by site-selective cleavage of the pure antibody and then was labeled with a fluorescent dye, Alexa Fluor 488. The ACE with LIF detection allows analysis of at least $100 \mathrm{pmol}$ of erythropoietins. Fluorescently labeled GTP analogs like BODIPY FL GTP $\gamma$ S (BGTP $\gamma$ S) are popular for the analysis of proteins like guanine-nucleotide binding proteins by ACE [192]. In the assay, BGTP $\gamma \mathrm{S}$ was incubated with samples containing guanine-nucleotide binding proteins and then the resulting mixtures of BGTP $\gamma$ S-G protein complexes and free BGTP $\gamma$ S were analyzed by ACE-LIF. Using a $50 \mathrm{nM}$
BGTP $\gamma$ S probe, BGTP $\gamma$ S-G peak heights increase linearly with $\mathrm{G}$ protein concentration up to $200 \mathrm{nM}$ and the LODs for $\mathrm{G}$ proteins is $2 \mathrm{nM}$. Because one analysis can be complete in less than $30 \mathrm{~s}$, the high-speed ACE assay allows reaction kinetics and dissociation constant $\left(K_{\mathrm{d}}\right)$ values to be determined [193].

Efficient ACE separations of proteins can also be achieved according to enzyme-substrate, peptide-protein, and DNA-protein interactions. ACE has been applied to understanding the selectivity of the binding interactions between proteins or peptides and the so-called quadruplex DNA (aptamers). A capillary coated with quadruplex DNA provides the separations of 14 different homodipeptides and nine different Ala-X dipeptides [194]. The results present that some amino acid combinations in the dipeptides have stronger binding forces with the quadruplex DNA than others. Aptamers are combinatorially developed to bind-specific targets and often contain G-quartet motifs, as is, e.g., the case for the thrombinbinding aptamer originally described more than 10 years ago [195]. Several studies have proved the feasibility of using CE for selecting and isolating high-affinity aptamers for specific targets such as neuropeptide $Y$ [196], IgE [197], and protein farnesyl-transferase [198]. Recently, Huang et al. [199] have demonstrated a human $\alpha$-thrombin binding aptamer labeled with 6-carboxyfluorescein for studying thrombin-protein interactions using CE with LIF detection. The electropherograms exhibit that the peak area of G-quadruplex aptamer decreases with the addition of thrombin while that of L-aptamer remains unchanges. The result also shows that the aptamerbased competitive ACE assay is effective to explore thrombin-antithrombin III interactions in real time. The LODs for thrombin and antithrombin III are 9.8 and $2.1 \mathrm{nM}$ when using the dye labeled aptamer. A technique socalled nonequilibrium $\mathrm{CE}$ of the equilibrium mixture (NECEEM) of a protein is effective for quantitative analyses of proteins by using its fluorescently labeled aptamer [200]. In NECEEM, a protein with a fluorescently labeled aptamer generates an electropherogram with three characteristic features, including the equilibrium amount of free aptamer in the equilibrium mixture, the amount of the protein-aptamer complex that remains intact at the time of detection, and the exponential part that is ascribed to the complex decaying during separation under nonequilibrium conditions. A simple analysis of the three features in NECEEM is useful for the determination of the equilibrium dissociation constant or protein concentration. One example of the NECEEM method is the analysis of thrombin using a fluorescein-labeled aptamer under the conditions at which the protein-aptamer complex completely decays during the separation, with an LOD of $4 \times 10^{6}$ molecules for thrombin. A similar NECEEM was 
further applied to determine the binding capabilities of dsDNA and ssDNA for the microtubule-associated tauproteins [201]. The results show that dsDNA may dissociate to form ssDNA that is actually bound to tau, contrary to earlier beliefs. By comparing the peak profiles between the electropherograms of preincubated mixtures in BGEs with/without containing a displacer of unbound material (ssDNA-binding protein from E. coli), the DNAtau binding is evident [202].

ACE is also a powerful tool for unraveling and characterizing intramolecular interactions such as those involved in protein folding. To resolve different conformations of proteins by ACE, their lifetimes have to be sufficiently long and their folding variations should impose sufficient changes in the shape/size or charge distribution, or exposure of interacting domains to induce changes in their electrophoretic velocities. Amyloid dye Congo red has been shown effective for identification of different conformations of amyloidogenic protein $\beta_{2}$-microglobulin in ACE with UV-Vis absorption detection [203]. The separation patterns are dependent on two selectivity factors conferred by intramolecular as well as intermolecular interactions. ACE is practical for exploring the interactions of proteins in various conformational structures with chiral drugs [204]. The conformational changes of HSA are evident through their binding with a basic drug (mexiletine) by ACE with UV-Vis absorption detection. Different protein conformers induced by $\mathrm{pH}$ changes, heat, acute vibration, and alcohol have various interactions (enantiomeric selectivity) with the drug. The changes in the conformation of globular metalloproteins bovine CA II in the presence and the absence of its $\mathrm{Zn}(\mathrm{II})$ cofactor are detectable by conducting ACE [205]. The protein is unfolding upon treatment with SDS and refolding upon removal of SDS. The results suggest that $\mathrm{Zn}(\mathrm{II})$ cofactor is not required for refolding into a native like conformation, does not remain associated with the unfolded protein, and does not significantly change the rate of refolding.

\section{Online sensitivity improvements}

\subsection{Stacking}

With a small sample volume injection and a short optical path length, CE techniques are sometimes not sensitive enough for the analysis of trace amounts of proteins. To overcome this disadvantage, a number of online concentration techniques have been developed, including field amplification stacking, ITP, IEF, pH-mediated approach and sweeping [206-213]. Field amplification stacking is one of the most popular stacking methods, in which the sample matrix has a low conductivity (usually a diluted buffer or water) than that of the buffer filled in a capillary [214]. As a relatively high electric field distributes across the sample zone, analytes within the sample zone are accelerated with a higher local velocity and become stacked at the boundary of the buffer zone in which their velocities are low. More than 100-fold improvements in sensitivity of trypsin inhibitor and $\alpha$-lactalbumin are real by conducting field amplification stacking in CE [215]. Concentrations and separations of ionic species (fluorescent dyes, amino acids, DNA, proteins, and particles) in a high conductivity buffer electrolyte within capillaries by temperature gradient were demonstrated [216]. By using an appropriate buffer, the temperature gradient generates a corresponding gradient in the electrophoretic velocity, so that the electrophoretic and bulk velocities sum to zero at a unique point and the analyte is focused at that point, resulting in greater than 10000 -fold concentration of a dilute analyte.

By taking the advantage of $\mathrm{pH}$ dependence of the mobility, an online concentration and separation of CE technique under discontinuous conditions is practical for the analysis of proteins and peptide mapping [217]. Because proteins possess greater positive charges and thus have greater mobility at low $\mathrm{pH}$, they are stacked when migrating to a buffer at high $\mathrm{pH}$. With a great stacking efficiency, casein at the concentration of $5.00 \mu \mathrm{M}$ is enough for obtaining a peptic mapping. By injecting $1.31 \mu \mathrm{L}$ of the peptic digests to a capillary in CE with UV detection at $280 \mathrm{~nm}$, there are 26 peaks for the peptide fragments displayed in the electropherogram. $\mathrm{pH}$ junctions in CE under a discontinuous electrolyte system is alternative for protein preconcentration [218]. $\mathrm{pH}$ junction can be generated by using discontinuous buffers of ammonium ( $\mathrm{pH}$ 9.25) and acetate ( $\mathrm{pH} 4.75)$, in which the proteins are captured at the $\mathrm{pH}$ near their pl's. This method allows a stacking efficiency of myoglobin greater than 1700-fold.

An online protein concentration technique using PEO solution has been developed for the analysis of proteins by CE in the presence of EOF [155]. Proteins slow down and are stacked as a result of sieving, increases in viscosity, and decreases in electric field when migrating from sample zone to PEO solution. With an injection volume of $2.1 \mu \mathrm{L}$, the LOD for CA by CE-LIF was at the pM level, with a 1500-fold sensitivity improvement. By applying a short plug of low pH buffer after sample injection, it is effective to increase injection volumes of high-conductivity protein samples when conducting the analysis in the presence of EOF using PEO solution [148]. The short plug plays a role in reducing the matrix effect, allowing analysis of greater volumes $(0.81 \mu \mathrm{L})$ of proteins that were prepared in PBS. 
A segmental filling method was demonstrated for the analysis of SYPRO Red-labeled SDS proteins using PEO solution, with the LODs of 0.35 and $0.10 \mathrm{nM}$ for BSA and $\beta$-casein, respectively [219]. In order to optimize resolution, speed, and stacking efficiency, a plug of $0.1 \%$ SDS was applied prior to injection of samples $(0.64 \mu \mathrm{L})$ that were prepared in Tris-borate buffer containing $50 \mathrm{mM}$ $\mathrm{NaCl}$ and SYPRO Red. More recently, use of Tris-borate solutions ( $\mathrm{pH} 10.0)$ containing either $0.01 \%$ SDS or $0.01 \%$ PEO to prepare protein samples has been demonstrated to be effective for improved stacking and separation efficiencies when conducting large-volume protein separation by CE-LIF using PEO [220]. The electropherograms are displayed in Fig. 1. The LODs for the proteins are on the nanomolar to subnanomolar level. For example, the LOD for $\alpha$-lactalbumin is $0.48 \mathrm{nM}$, which is an 84-fold improvement in sensitivity when compared to that obtained without stacking. The plate numbers for the proteins are all $>10^{5}$ (e.g., $>1.0 \times 10^{6}$ for trypsin inhibitor), which indicates a high stacking efficiency and minimum protein adsorption. By applying a short plug of SDS prior sample injection, a greater number of peaks, representing the microheterogeneity of the proteins, were resolved as shown in Figs. $1 \mathrm{~B}$ and $\mathrm{C}$. This method allowes one to detect 12 peaks as displayed in Fig. $1 \mathrm{C}$ when injecting $1.0 \mu \mathrm{L}$ of a sample containing six-model proteins $(0.1 \mu \mathrm{M})$.

The aforementioned CIEF methods are effective for sample enrichment [84, 208, 221]. Instead of using sample injection, CIEF involves filling of the entire capillary with a solution mixture containing samples and carrier ampholytes. The focusing effect of CIEF contributes not only to a high-resolution separation of proteins/peptides having different $\mathrm{p} /$ values but also to providing a typical stacking efficiency of more than 100 times. To further enhance the sample loading volumes for greater concentration effects, dynamic introduction of proteins/peptides using electrokinetic injection from the solution reservoir has been demonstrated in CIEF using a capillary initially filled with a carrier ampholyte solution [208]. Upon the application of electric potentials, a $\mathrm{pH}$ gradient inside the capillary is rapidly established, which is contributed by the presence of the small and highly mobile carrier ampholytes. The feature of this technique has been tested for the analysis of low pl proteins (standards) and tryptic peptides from $S$. cerevisiae (yeast). By comparison with the concentrations of dilute yeast peptides originally present in the reservoir, this approach provides an overall stacking efficiency of 1400-7700 together with excellent separation resolution. With such a great stacking efficiency, this approach allows detection of $10 \mathrm{pg} / \mu \mathrm{L}$ of bradykinin peptide spiked in a yeast protein digest using UV-Vis absorption detection.

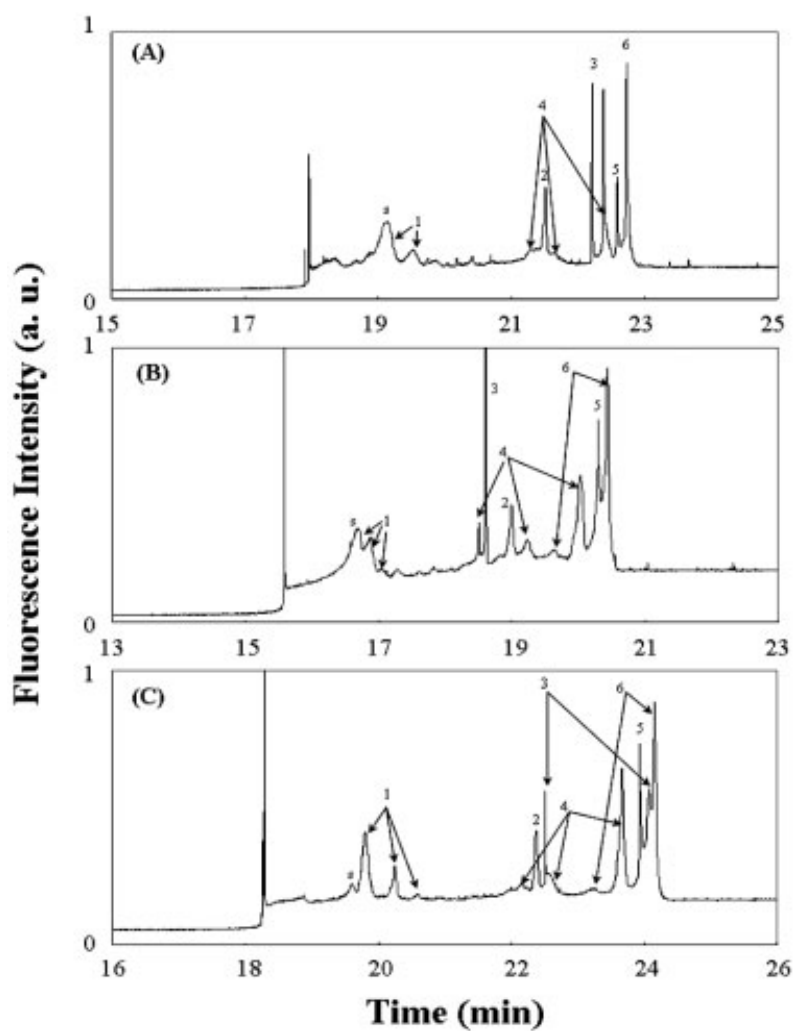

Figure 1. Separations of $1.0-\mu \mathrm{L}$ protein samples by $\mathrm{CE}$ with LIF detection in the $(A)$ absence and $(B, C)$ presence of an SDS plug $(0.2 \%$, ca. $2.5 \mathrm{~cm})$ at $12.5 \mathrm{kV}$ using PEO. The samples in $(A)$ and $(B)$ were prepared in $10.0 \mathrm{mM}$ TB solutions $(\mathrm{pH} 10.0)$ containing $0.01 \%$ SDS, while those in (C) were prepared in $10.0 \mathrm{mM}$ Tris-borate solution (pH 10.0) containing 0.01\% PEO. Protein concentrations were $0.1 \mu \mathrm{M}$. Peak identities: s, system peak; 1 , carbonic anhydrase (CA); 2, trypsin inhibitor; 3 , $\alpha$-lactalbumin; 4, BSA; 5 , $\beta$-casein; 6 , ovalbumin. The fluorescence intensities are plotted in arbitrary units (a.u.). Reprinted from [220], with permission.

ITP is an alternative sample stacking method for proteins [209, 222, 223]. ITP coupled with zone electrophoresis (ZE) with LIF detection is a method of choice for increasing the sensitivity of proteins particularly when plastic microfluidic devices are used. Plastic multichannel chips are usually designed with long sample injection channel segments to increase sample loading volumes [222]. After the sample is stacked into a narrow band by discontinuous ITP buffers, ZE is then applied to separate the analytes. By injecting a 2-cm plug of fluorescently labeled ACLARA eTag reporter, a 400-fold sensitivity improvement over chip ZE was achieved without loss in resolution. The ITP-ZE method allows the analysis of a cell surface protease (ADAM 17) in live intact cells in physiological buffers, with an LOD of 10 cells per assay. An ITP-GE with LIF detection was conducted for improved sensitivity for proteins in the presence 
of SDS using a glass microchip [223]. Without deteriorating the peak resolution, four FITC-labeled SDS proteins (CA, ovalbumin, BSA, and conalbumin) were analyzed by using the integrated ITP-GE system, with a result of 40 -fold sensitivity improvement when compared to that by conducting a GE mode only.

As a stand-alone separation technique, capillary ITP (CITP)-MS was first applied to peptides and proteins [224]. A system combined CITP with ESI was illustrated for the analysis of mixtures of peptides and proteins, with LODs of ca. $100 \mathrm{fmol}$ for myoglobin and cytochrome c. After injection of up to $10 \mu \mathrm{L}$ angiotensin peptides, CITP with TOFMS was applied, resulting in a great sensitivity enhancement when compared to that by typical nanoliter-sized injection volumes in CE [225]. Metal-binding proteins such as $\mathrm{Hb}, \mathrm{CA}$, and superoxide dismutase of clinical relevance were concentrated in uncoated fused-silica capillaries by CZE coupled with transient CITP (tCITP) [226]. In the tCITP-CZE system, $125 \mathrm{mM}$ ammonium formate solution (pH 4.0) is the leading electrolyte in tCITP and $1 \mathrm{M}$ formic acid solution $(\mathrm{pH} \mathrm{1.8)}$ is the BGE in CZE. CZE itself provides the separation efficiency of 165000 theoretical plates $/ \mathrm{m}$ and the tCITP-CZE offers the separation efficiency up to 230000 plates $/ \mathrm{m}$. tCITP is also convenient for preconcentration of SDS-protein complexes (phosphorylase $b$, albumin, ovalbumin, CA, trypsin inhibitor, and $\alpha$ lactalbumin) when using a single channel chip [227]. The LODs for the proteins are all around $0.27 \mu \mathrm{g} / \mathrm{mL}$ by CE with UV-Vis absorption detection at $214 \mathrm{~nm}$.

\subsection{SPME}

SPME methods have become popular because they provide greater extraction efficiency and significantly decrease extraction times and cost of operations when compared with liquid-liquid extraction methods. In recent years, we have witnessed advances in online SPME-CE, particularly online IACE $[185,206,207]$. SPME devices or analyte concentrators-microreactors are designed for selective and nonselective recognition reactions. They can be directly placed near the inlet of the separation capillary having two frits [228] or without frits [229]. They can also be immobilized on beaded or monolithic packing structures bonded to the capillary [230-232] or directly attached to the capillary wall [187]. An SPME in combination with CIEF was demonstrated for the analysis of proteins with LIF detection [233]. Unlike other liquidphase separation methods and conventional CIEF, proteins are focused into stationary bands within a $\mathrm{pH}$ gradient in CIEF with a whole-column imaging detection (WCID). By combining SPME and CIEF-WCID, desorption time can be controlled to allow complete desorption without generating any band broadening. This method allows extraction of $R$-phycoerythrin in water by SPME within $10 \mathrm{~min}$, and subsequent analysis of the desorbed proteins by CIEF-LIF-WCID within $20 \mathrm{~min}$, resulting in an LOD of $3.5 \mathrm{pM}$. The method is practical for the analysis of extracellular phycoerythrins in cultured cyanobacteria samples.

\section{Multidimensional separation techniques}

\subsection{LC-CE}

Owing to a greater sample loading capacity of HPLC (commonly RPLC) than that of CE, it is generally conducted in the first dimension in 2-D separation systems of HPLC combined with CE. When conducting 2-D protein separation, the loss of sensitivity due to dilution, sample overloading in the second separation mode, and peak broadening due to imperfect interfaces may occur. Comprehensive 2-D liquid-phase separation systems with switching interfaces were pioneered by Bushey and Jorgenson in the late 1980s [234-236]. Since then, many excellent interfaces have been developed for 2-D separation systems for protein analysis [237-242]. Figure 2 displays four representative interfaces that have been tested for protein analysis. The use of a sample loop (Fig. 2A) to interface micro-LC column with CZE is attractive because of higher efficiencies and reduced sample dilution that are inherent in this conjugation. However, collection of a sample in a loop is impractical due to limited volumes of eluted mobile phase and a difficulty in transferring minute quantities of material without loss, dilution, or dispersion of the sample by using a micro column. Figure 2B represents an instrumental setup of a so-called transverse flow gating interface that allows operation under small flow rates [237]. In the interface, a crossflow of buffer is applied. The crossflow is the buffer flow from the CE buffer reservoir via the "flush buffer in" to the waste via "flush buffer out." The crossflow controls the injections of eluted LC mobile phase onto the CE capillary. Other interfaces, such as optical gating interface, have also been developed for more comprehensive 2-D separations of proteins [237-242]. The optical gating interface shown in Fig. $2 \mathrm{C}$ is useful for "fast-CZE" systems. Ninety-five percent of the beam's power from the laser is split into a gating beam, focused nearer the injection end of the capillary, and a probe beam that contains about $5 \%$ of the laser power and is focused nearer the exit end of the capillary. To make an injection, the gating beam is momentarily blocked with a computer-controlled shutter. This allows a small plug of samples that are tagged with FITC to pass through and are then separated by CZE. By this configuration, complete CZE analyses as 
(A)
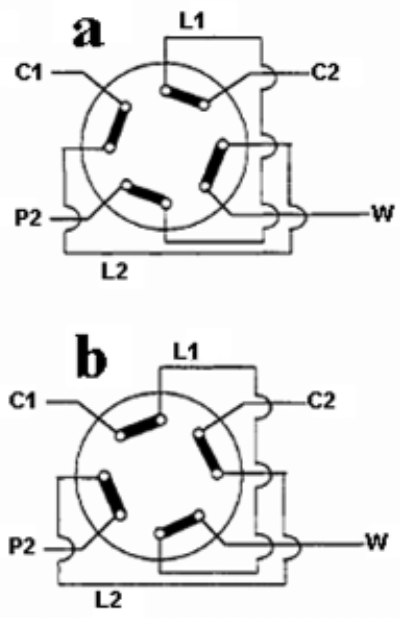

(C)

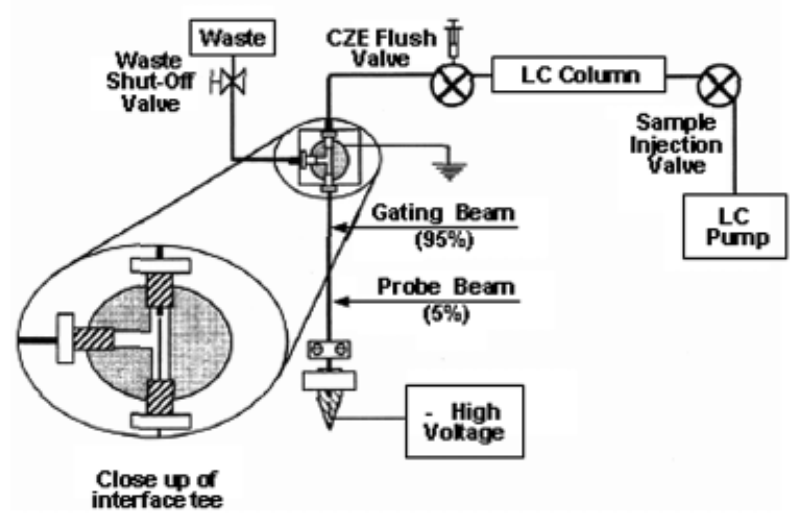

(B)

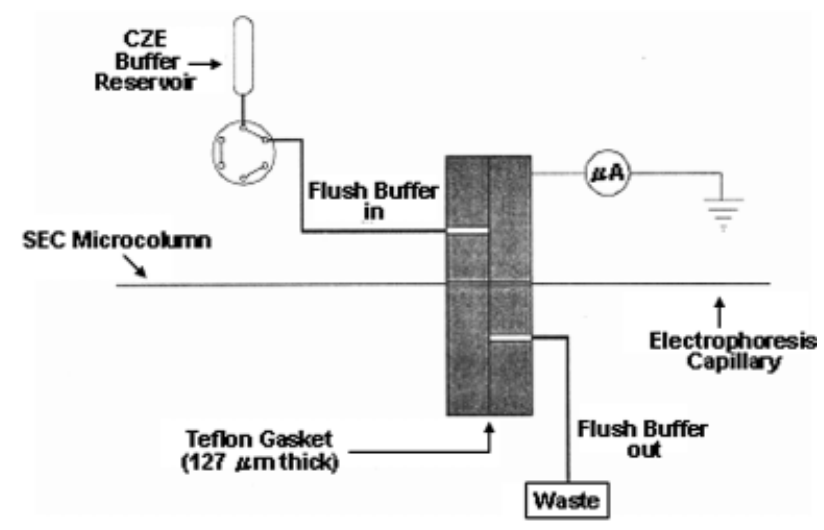

(D)

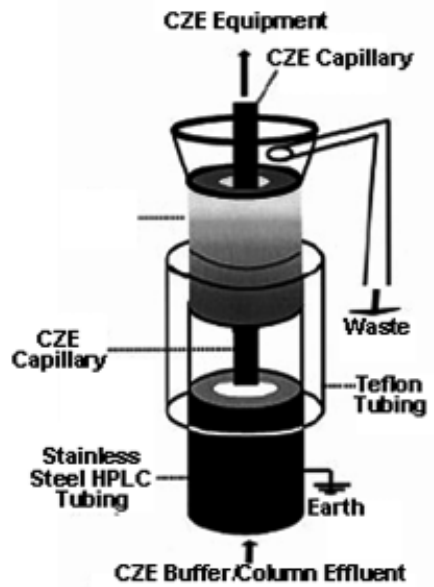

Figure 2. Schematic representation of different LC-CE interfaces. (A) Eight-port, computer-controlled valve; (B) opticalgating injection system; (C) flow gating interface; (D) T-piece interface. Reprinted from [234, 237, 239, 242], with permission.

little as $3 \mathrm{~s}$ is possible while high separation efficiency is maintained [238]. Although it is rapid, the approach is only limited to fluorescent analyte derivatives and requires a high power laser source. Moreover, a size-exclusion chromatography (SEC)-CE system has been developed for the analysis of peptides in biological samples [242]. The schematic representation of the interface is displayed in Fig. 2D. SEC separation is followed by a trapping procedure on an RP18 microcolumn with subsequent elution of the trapped fraction and separation by CZE for the quantification of structural-related peptides in biological matrices.

It is estimated that as many as 10000 unique proteins are present within the human serum proteome that span a dynamic range of concentration estimated to be greater than $10^{9}$ [243]. Under normal physiological conditions, the components of the serum proteome are selfregulated with the overall protein concentration maintained at about
$60-80 \mathrm{mg} / \mathrm{mL}$. Dramatic changes in protein quality or quantity often signal abnormality and pathological changes in the human body. Moreover, subtle changes of low-abundance proteins have also been linked to the development of different diseases. Recent reports have demonstrated that serum protein profiles are useful and feasible for early detections of ovarian [244], prostate [245, 246], and breast cancers [247]. A RPLC-CZE method combined with MS/MS detection through a sheathless ESI interface was used for the identification of proteins in a serum sample. In order to achieve minimum matrix interference, prior to MS/MS analysis, the serum samples are subjected to methanol precipitation to remove the high-abundance proteins [248]. As the amount of albumin (and other high-abundance proteins) is greatly diminished in the precipitated serum sample, the low-abundance, low-MW species are greatly enriched in the serum sample. Complex peptides mixtures from tryptic digestion are 
first separated by RPLC into fractions with minimal overlap between neighboring fractions. Collection of a large number of fractions does not prohibitively increase the total analysis time of the 2-D methods because the CZE analysis time (20 $\mathrm{min}$ ) is relatively short.

A comprehensive 2-D system-coupling capillary RPLC (CRPLC) with CIEF was demonstrated for the separation of complex protein/peptide sample of yeast cytosol [249]. The focusing effect of CIEF not only contributes to a highresolution protein/peptide separation, but also permits the analysis of low-abundance proteins with a typical stacking efficiency of 50-100-fold. Because cRPLC has an orthogonal separation mechanism to CIEF, the 2-D system provides high-resolution separation for proteins, with a peak capacity of more than 10000. Recently, cRPLC (first dimension) coupled to an array CIEF (second dimension) with a novel WCID has been developed for peptide mapping [250]. An array of up to 60 capillaries was assembled in the system, allowing quantitative detection of thousands of focusing protein bands. The practicality of the cRPLCarray CIEF-LIF-WCID system was validated for the analysis of soluble proteins extracted from liver cancer tissues. The overall peak capacity is estimated to be around 18000 in an analysis time of less than $3 \mathrm{~h}$.

CSF is a secretion product of several central nervous system structures, mainly in the choroid plexus of the brain ventricles [251]. It contains an abundance of neuropeptides, proteins, amino acids, and catecholamines circulates within the ventricles of the brain and surrounds the brain as well as spinal column. For example, the normal concentration of $\beta$-trace protein in CSF is at the level of $27.9 \mu \mathrm{g} / \mathrm{mL}$ [252]. Characterization of CSF has significantly clinic merits that are useful in the diagnosis and management of neurological diseases such as Alzheimer's and Parkinson's diseases [253-255]. An SEC separation followed by a trapping procedure on a $4 \mathrm{~mm} \times 3 \mathrm{~mm}$ id RP C18 column with subsequent elution of the trapped fraction and separation by CZE was demonstrated for quantitative determination of a CSF sample spiked with six enkephalins (neuropeptides with a morphinomimetical action), with a satisfactory linearity and intraday precision [242, 256]. The RP18 trapping device is used to remove the ammonium acetate from the peptide fraction eluting from the SEC column and also to concentrate the analytes of interest. The LOQs of the analytes by this hyphenated system with UV detection are all about $2.5 \mu \mathrm{g} / \mathrm{mL}$, showing its potential for the determination of exogenous drugs (peptides and proteins) in biological systems. The construction and expansion of the database of human plasma proteins with (MW/p/) loci provides a valuable tool in clinical analysis, for instance in the detection, diagnosis, and treatment of human cancer
[257]. An online coupling of gel filtration chromatography with CIEF using a membrane interface was tested for plasma protein analysis in clinical laboratories [258]. Efficient desalting by the sample loop membrane interface ensures successful CIEF analysis in the second dimension even in the presence of physiological levels of salt in the whole blood samples. Two major variants of $\mathrm{Hb} \mathrm{A}$ and glycated $\mathrm{HbA}_{1 \mathrm{c}}$ were determined by using a whole-column absorption image system.

\subsection{CE-LC}

Online integration of CIEF with cRPLC using a microinjector interface was demonstrated for the analysis of Drosophila proteomics during steroid-induced programmed cell death time [259]. Repeated injections followed by multiple cRPLC separations were performed until the entire CIEF capillary content was sampled, separated, and detected with UV detection. CIEF provides the advantages of high resolution, concentration, and $\mathrm{p} /$ information for the proteins in each fraction. The overall peak capacity is estimated to be around 1800 over a run time of less than $8 \mathrm{~h}$, displaying significant differences in the separation profiles of peptide samples obtained from salivary glands of animals staged at the 6 and $12 \mathrm{~h}$ following puparium formation. The system was further modified by adding an IT MS and replacing the loop with 12 trapping columns that avoid the need to maintain the CIEF separation through numerous LC runs. A schematic overview for the online integration of CIFF with CRPLC as a concentrating and multidimensional separation platform is shown in Fig. 3 . The peak capacity is 2640 for a tryptic digest of yeast soluble lysate. In addition, MS/MS data and database searching allow identification of 1484 proteins. The system only requires a protein loading of $9.6 \mu \mathrm{g}$, which is $2-3$ orders of magnitude lower than those employed by the reported nongelbased proteome techniques. By reducing the inner diameter of chromatography columns from 180 to $100 \mu \mathrm{m}$, the required protein loading is further decreased from $9.6 \mu \mathrm{g}$ to $960 \mathrm{ng}$, illustrating the potential usage of this proteome technology for the analysis of protein profiles within small cell populations or limited tissue samples [84].

Typically, the analysis of large quantities of cellular proteins and/or enzymatically/chemically cleaved peptides ranging from a few milligrams to several hundred micrograms is required to extend the proteome coverage [260264]. This goal is sometimes not easy to be achieved because only limited sample amounts ranging from $10^{3}$ to $10^{5}$ cells are generally available in mammalian proteomics, corresponding to a total protein content of 0.1-10 $\mu \mathrm{g}$. By using CIEF-nano-RPLC, a total of 6866 fully tryptic 


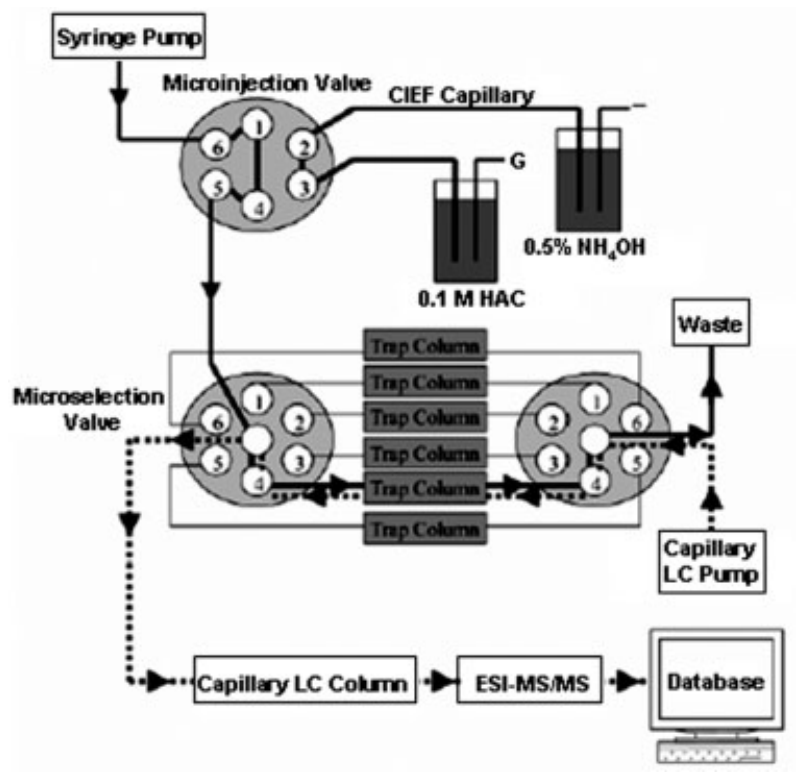

Figure 3. Schematic of online integration of CIEF with cRPLC as a concentrating and multidimensional separation platform. Solid and dashed lines represent the flow paths for the loading of CIEF fractions and the injection of fractions into a cRPLC column, respectively. Reprinted from [84], with permission.

peptides were separated, leading to the identification of 1820 distinct proteins [265]. The system allows generation of high mass accuracy and high-confidence identifications from three proteome runs of a single glioblastoma multiforme tissue sample. Another advantage of this approach is only as low as $10 \mu \mathrm{g}$ of total proteins required for each run. A technique (IEF as first dimension and nonporous-RPLC as second dimension) was developed for the analysis of protein extracts from breast cancer cell lysates, with a high-sequence coverage [266]. Individual protein fractions were purified and separated using the multidimensional separation approach and their trypic digests were then analyzed by both MALDI-TOF-MS and (CE-ESI)-TOF-MS peptide mapping systems. Using combined sequence information provided by both mapping methods, $100 \%$ sequence coverage is often obtained for smaller proteins, while it is $90 \%$ coverage for larger proteins up to $75 \mathrm{kDa}$. The intact protein MW together with high-coverage-sequence information provides accurate identification of the presence of lamin isoforms and their corresponding modifications. By using a microdialysis membrane-based cathodic cell, a CIEFRPLC-MS system allows protein fractions to be collected, washed to remove ampholyte, and analyzed by RPLCMS [267]. Seven fractions in the $\mathrm{p} /$ range 3-10 from CIEF were further analyzed by RPLC-MS in $2 \mathrm{~h}$, leading the detection of proteins at the low-femtomole level.

\subsection{CE-CE}

Compared to LC-CE combinations, a CE-CE coupling is usually easier because the effluent peak of the first capillary has generally a volume similar to the injection amount on the second capillary. Usually, the combination of CE-CE format commonly conducted in the configuration that the first $C E$ mode is for concentrating analytes and the second CE mode provides high-efficiency separation [268]. A CITP-CZE system using two fluorinated ethylene-propylene copolymer capillaries [269] was demonstrated for protein analysis. CITP serves as an efficient preseparation (removing bulk components) and concentration (stacking) stage which focus large volumes (may be greater than the total capillary volume used in CZE) of proteins in the larger inner diameter capillary. After online transfer of the sample into the second capillary, CZE with a UV detection at $254 \mathrm{~nm}$ proceeds for efficient analysis. This combination allows detection of $0.25 \mu \mathrm{g} / \mathrm{mL}$ lysozyme and quantification of the egg content in egg pasta.

By using a dialysis interface, a 2-D hyphenated system consisting of CIEF coupled with either CZE or CGE was proved to be useful for the analysis of $\mathrm{Hb}$ variants [270, 271]. The dialysis membrane interface that is placed between CIEF and CZE or CGE allows removal of the mobilizing salt before the sample zones are subjected to second-dimensional separation, resulting in improved resolution and sensitivity. With the advantages of minimum dead volumes, simplicity, and ruggedness, an etched porous glass interface was used in an online coupling CEbased multiple dimensional separation system [272]. A CIEF-CGE system containing a porous glass interface offers high stacking efficiencies and high resolving power for ionic proteins with different sizes. A microdialysis junction as the interface for online combination of CIEF with tCITP-CZE coupled with ESI-FTICR-MS was demonstrated for high-resolution and sensitive analysis of complex proteome mixtures [221, 273]. The electrokinetic focusing/stacking effects of CIEF and CITP greatly enhance the dynamic range and detection sensitivity of MS for protein identification. With high stacking efficiencies, the system allows the analysis of only $500 \mathrm{ng}$ of proteolytic digests. A total of 1174 unique proteins, corresponding to a $26.5 \%$ proteome coverage, from the cytosolic fraction of Shewanella oneidensis were identified.

A 2-D system of MEKC and CIEF-WCID was developed for the separations of trypsinogen digest and cytochrome $c$ digests [274]. A key to the success of the system is the use of a ten-port valve as the interface for the two orthogonal separations. The valve contains two conditioning loops in which salt and unwanted first-dimension effluent components are eliminated by dialysis and carrier ampholytes are added. A system consisting of submicellar CE coupled to 
CZE-LIF is useful for the analysis of proteins, labeled with a fluorogenic reagent [275]. The system allows detection of zeptomoles of labeled proteins from HT29 cell lysates. A system in a configuration of capillary sieving electrophoresis with MEKC was tested for the study of protein expression in single mammalian cells [276]. After a 6 min long sizebased separation using SDS-pullulan buffer, over 100 transfers of fractions from the first capillary were introduced into a second capillary for further separation by MEKC over an approximately $3.5 \mathrm{~h}$ long period. The ability of the system for sensitive protein profiling was validated through the generation of protein fingerprints from single native MC3T3-E1 osteoprogenitor cells and MC3T3-E1 cells transfected with the human transcription regulator TWIST as displayed in Fig. 4. The overexpression of this single transcription regulator has a profound influence on both the visual appearance of the cell and on the single-cell electropherogram. The striking differences in the appearance of the cells with and without transfection can only arise from differences in the expression of highly expressed structural proteins; these structural proteins likely form a significant fraction of the proteins observed in the single-cell electropherogram. The same 2-D separation technique was demonstrated for the analysis of Deinococcus radiodurans protein homogenate, with a total of 150 partially resolved peaks [277]. The 2-D separation system provides a 550 spot capacity, which is lower than the theoretical expectation; a spot capacity of 6750 is expected based on the fact that 1-D capillary sieving electrophoresis and MEKC separations generated peak capacities of 75 and 90 , respectively. The peak capacity in the CSE and MEKC dimensions appears to be dominated by diffusion during the long separation time and by the transfer time as well as the relatively short separation time, respectively. Thus, the authors have suggested several strategies to speed up the separation in order to achieve greater spot capacity, including use of shorter capillaries, conducting the separation at high electric fields, changing the buffer compositions and decreasing the sieving matrix concentration, and so on.

\section{Conclusions}

We briefly review several CE techniques for protein analysis, including CZE, CIEF, CEC, and ACE. Each technique has its advantages and disadvantages over the others for protein analysis. Thus the separation capacity and sensitivity improvements can be improved by using hyphenated separation techniques such as a combination of CIEF with CZE. With the advantages of reasonable

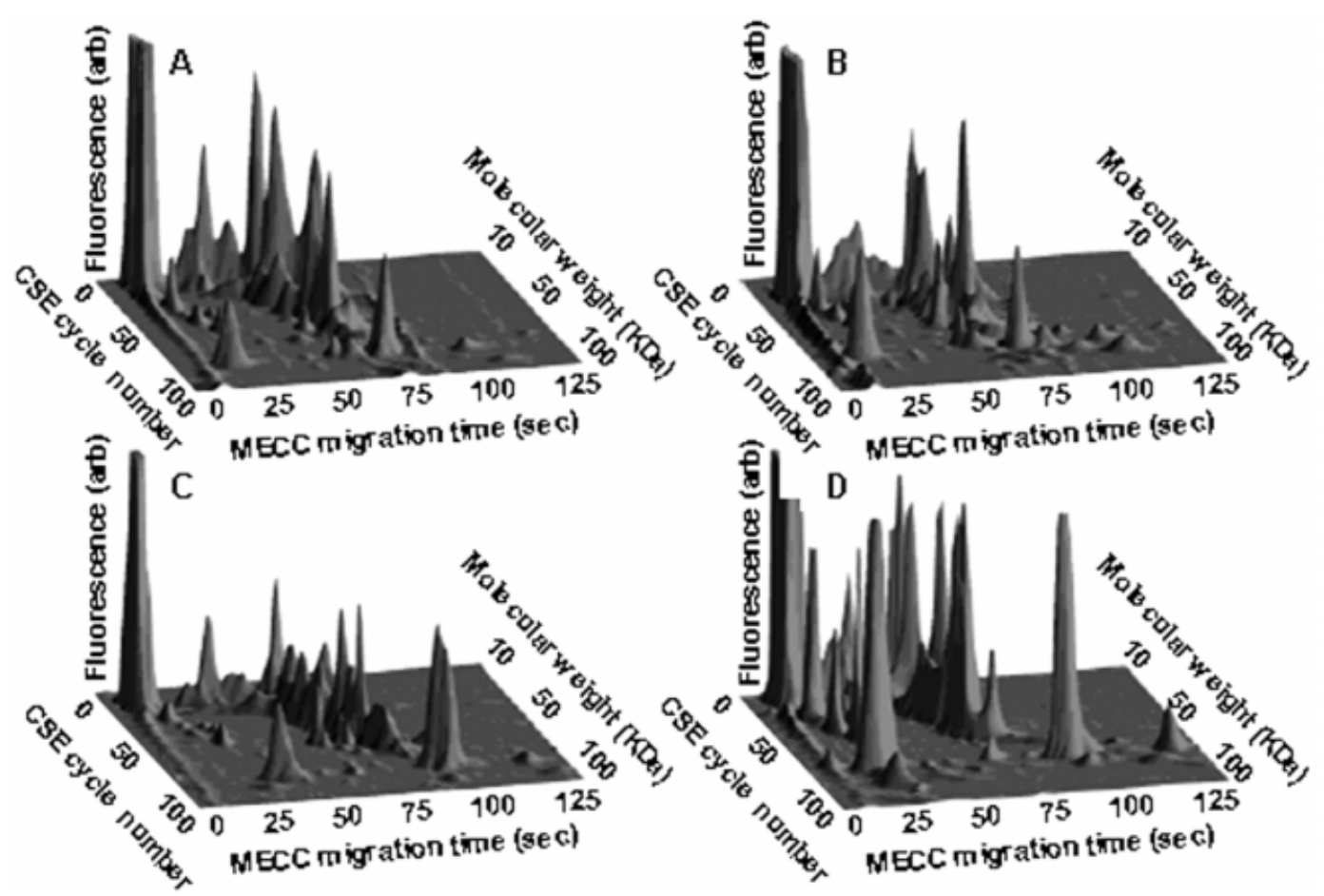

Figure 4. Protein landscape images from single MC3T3-E1 cells. Landscapes $A-C$ were generated from untransfected cells. Landscape D was generated from a single MC3T3-E1 cell that had been transfected with the transcription regulator TWIST. Reprinted from [276], with permission. 
throughput, automation capability, sensitivity, and highresolving power, several multidimensional separation techniques such as RPLC-CE and CE-CE in combination with MS detection hold great potential for proteomics. However, we have to point out that none of the developed 2-D CE-based separation systems has been commercialized, mainly because of each system having its own limitation to certain biological samples, poor reproducibility, complicated configurations, and requirements of skilled operators. In addition, the peak capacity and dynamic range of those systems are still not good enough for proteomics. For those reasons, they have not been able to compete with 2-D HPLC-ESI-MS methods for proteomics in this stage although they may provide greater peak capacity. Thus, techniques providing high sensitivity and peak capacity are still highly demanded for the analysis of biological samples that contain a great number of proteins and peptides with a large variation of protein-relative abundances. To further enhance the peak capacity, multidimensional techniques such as array-HPLC-CE, RPLC-CIEF-CE, and RPLC-CIEF-CGE are worth being tested. The success of these developing techniques heavily relies on fabricating novel interfaces that allow automatic and precise control of the analytes of interest flowing from one channel to the other. Once the separation systems can provide extremely high-resolving power and throughput for proteomics, the burden of use of high-cost MS/MS detection systems should be reduced and more detailed bioinformation could be obtained as a result of greater protein coverage.

In order to identify trace proteins, techniques allow removal of abundant proteins such as albumin and/or highly selective concentrations of trace proteins of interest are essential. Possible candidates for such high-efficient concentrators are molecular imprinted polymers, polymers containing antibodies or aptamers, and bioconjugated nanoparticles such as aptamers bound gold nanoparticles and antibodies conjugated magnetic nanoparticles. In order to gain more informative data for understanding cell functions such as cell differentiation, growth, malfunction, and communication, a great number of samples have to be analyzed and the obtained data are required to be carefully encoded to establish useful biological information. It is thus important to have integrated collaboration among at least chemists, biologists, and engineers for fabrication of high-throughput, efficient, and sensitive CE-based systems for proteomics.

This work was supported by the National Science Council of Taiwan under contract numbers NSC 94-2113-M-002008 and NSC 94-2113-M-002-036.

\section{References}

[1] Hebestreit, H. F., Curr. Opin. Pharmacol. 2001, 1, 513-520.

[2] Hood, L., J. Proteome Res. 2002, 1, 399-409.

[3] Figeys, D., Anal. Chem. 2002, 74, 413A-419A.

[4] Chaudhuri, A., Chant, J., Bioessays 2005, 27, 958-969.

[5] Liu, B.-F., Xu, B., Zhang, G., Du, W., Luo, Q., J. Chromatogr. A 2006, 1106, 19-28.

[6] Hernandez, P., Müller, M., Appel, R. D., Mass Spectrom. Rev. 2006, 25, 235-254.

[7] Ivanov, Y. D., Govorun, V. M., Bykov, V. A., Archakov, A. I., Proteomics 2006, 6, 1399-1414.

[8] Tate, E. W., Signal Trans. 2006, 6, 144-159.

[9] Reinders, J., Sickmann, A., Proteomics 2005, 5, 4052-4061.

[10] Dolník, V., Liu, S., J. Sep. Sci. 2005, 28, 1994-2009.

[11] Kolch, W., Neusüâ, C., Pelzing, M., Mischak, H., Mass Spectrom. Rev. 2005, 24, 959-977.

[12] Marko-Varga, G. A., Nilsson, J., Laurell, T., Electrophoresis 2004, 25, 3479-3491.

[13] Dowsey, A. W., Dunn, M. J., Yang, G.-Z., Proteomics 2003, 3, 1567-1596.

[14] Gromov, P. S., Østergaard, M., Gromova, I., Celis, J. E., Prog. Biophys. Mol. Biol. 2002, 80, 3-22.

[15] Görg, A., Weiss, W., Dunn, M. J., Proteomics 2004, 4, 36653685.

[16] Honoré, B., Østergaard, M., Vorum, H., Bioessays 2004, 26 , 901-915.

[17] Shen, Y., Smith, R. D., Electrophoresis 2002, 23, 3106-3124.

[18] Jorgenson, J. W., Lukacs, K. D., Anal. Chem. 1981, 53, 1298-1302.

[19] Kašičká, V., Electrophoresis 2006, 27, 142-175.

[20] Huck, C. W., Bakry, R., Bonn, G. K., Electrophoresis 2006, 27, 111-125.

[21] Dolník, V., Electrophoresis 2006, 27, 126-141.

[22] Lacroix, M., Poinsot, V., Fournier, C., Couderc, F., Electrophoresis 2005, 26, 2608-2621.

[23] Chang, H.-T., Huang, Y.-F., Chiou, S.-H., Chiu, T.-C., Hsieh, M.-M., Curr. Proteomics 2004, 1, 325-247.

[24] Hsieh, M.-M., Chiu, T.-C., Tseng, W.-L., Chang, H.-T., Curr. Anal. Chem. 2006, 2, 17-33.

[25] Giddings, J. C., United Separation Science,John Wiley \& Sons, New York 1991.

[26] Huck, C. W., Stecher, G., Bakry, R., Bonn, G. K., Electrophoresis 2003, 24, 3977-3997.

[27] Wang, H., Hanash, S., J. Chromatogr. B 2003, 787, 11-18.

[28] Issaq, H. J., Chan, K. C., Janini, G. M., Conrads, T. P., Veenstra, T. D., J. Chromatogr. B 2005, 817, 35-47.

[29] Stroink, T., Ortiz, M. C., Bult, A., Lingeman, H. et al., J. Chromatogr. B 2005, 817, 49-66.

[30] Cooper, J. W., Wang, Y., Lee, C. S., Electrophoresis 2004, 25, 3913-3926.

[31] Evans, C. R., Jorgenson, J. W., Anal. Bioanal. Chem. 2004, 378, 1952-1961.

[32] Liu, H., Yang, C., Yang, Q., Zhang, W., Zhang, Y., J. Chromatogr. B 2005, 817, 119-126.

[33] Cottet, H., Biron, J.-P., Taillades, J., J. Chromatogr. A 2004, 1051, 25-32.

[34] Woods, L. A., Roddy, T. P., Ewing, A. G., Electrophoresis 2004, 25, 1181-1187.

[35] Guzman, N. A., Phillips, T. M., Anal. Chem. 2005, 77, 60A$67 A$. 
[36] Bandilla, D., Skinner, C. D., J. Chromatogr. A 2004, 1044, 113-129.

[37] Ferguson, K. A., Metabolism 1964, 13, 985-1002.

[38] Jing, P., Kaneta, T., Imasaka, T., Electrophoresis 2002, 23, 550-555.

[39] Holland, L. A., Leigh, A. M., Electrophoresis 2003, 24, 29352939.

[40] Vo, T. U., McGown, L. B., Electrophoresis 2006, 27, 749756.

[41] Okanda, F. M., El Rassi, Z., Electrophoresis 2005, 26, 19881995.

[42] Hilder, E. F., Svec, F., Fréchet, J. M. J., J. Chromatogr. A 2004, 1044, 3-22.

[43] Fu, H., Huang, X., Jin, W., Zou, H., Curr. Opin. Biotechnol. 2003, 14, 96-100.

[44] Lin, Y.-W., Chiu, T.-C., Chang, H.-T., J. Chromatogr. B 2003, 793, 37-48.

[45] Palm, A., Zaragoza-Sundqvist, M., Marko-Varga, G., J. Sep. Sci. 2004, 27, 124-128.

[46] Olivares, J. A., Nguyen, N. T., Yonker, C. R., Smith, R. D., Anal. Chem. 1987, 59, 1230-1232.

[47] von Brocke, A., Nicholson, G., Bayer, E., Electrophoresis 2001, 22, 1251-1266.

[48] Gelpí, E., J. Mass Spectrom. 2002, 37, 241-253.

[49] Simpson, D. C., Smith, R. D., Electrophoresis 2005, 26, $1291-1305$

[50] Fliser, D., Wittke, S., Mischak, H., Electrophoresis 2005, 26, 2708-2716.

[51] Hernández-Borges, J., Neusüß, C., Cifuentes, A., Pelzing, M., Electrophoresis 2004, 25, 2257-2281.

[52] Schmitt-Kopplin, P., Frommberger, M., Electrophoresis 2003, 24, 3837-3867.

[53] Neusüß, C., Pelzing, M., Macht, M., Electrophoresis 2002, 23, 3149-3159.

[54] Kaiser, T., Wittke, S., Just, I., Krebs, R. et al., Electrophoresis 2004, 25, 2044-2055.

[55] Smith, R. D., Wahl, J. H., Goodlett, D. R., Hofstadler, S. A., Anal. Chem. 1993, 65, 574A-584A.

[56] Stutz, H., Electrophoresis 2005, 26, 1254-1290.

[57] Na, D. H., Youn, Y. S., Lee, S. D., Son, M.-W. et al., J. Control. Release 2003, 92, 291-299.

[58] Rejtar, T., Hu, P., Juhasz, P., Campbell, J. M. et al., J. Proteome Res. 2002, 1, 171-179.

[59] Zuberovic, A., Ullsten, S., Hellman, U., Markides, K. E., Bergquist, J., Rapid Commun. Mass Spectrom. 2004, 18, 2946-2952.

[60] Musyimi, H. K., Narcisse, D. A., Zhang, X., Stryjewski, W. et al., Anal. Chem. 2004, 76, 5968-5973.

[61] Preisler, J., Hu, P., Rejtar, T., Moskovets, E., Karger, B. L., Anal. Chem. 2002, 74, 17-25.

[62] Cifuentes, A., Santos, J. M., deFrutos, M., Díez-Masa, J. C., J. Chromatogr. 1993, 652, 161-170.

[63] Towns, J. K., Regnier, F. E., Anal. Chem. 1991, 63, 11261132.

[64] Cretich, M., Chiari, M., Pirri, G., Crippa, A., Electrophoresis 2005, 26, 1913-1919.

[65] Moseley, M. A., Deterding, L. J., Tomer, K. B., Jorgenson, J. W., Anal. Chem. 1991, 63, 109-114.

[66] Goodlett, D. R., Wahl, J. H., Udseth, H. R., Smith, R. D., J. Microcol. Sep. 1993, 5, 57-62.

[67] Aguilar, C., Hofte, A. J. P., Tjaden, U. R., van der Greef, J., J. Chromatogr. A 2001, 926, 57-67.
[68] Thompson, T. J., Foret, F., Vouros, P., Karger, B. L., Anal. Chem. 1993, 65, 900-906.

[69] Cole, R. B., Varghese, J., McCormick, R. M., Kadlecek, D., J. Chromatogr. A 1994, 680, 363-373.

[70] Wang, Z., Prange, A., Anal. Chem. 2002, 74, 626-631.

[71] Hjertén, S., J. Chromatogr. 1985, 347, 191-198.

[72] Cobb, K. A., Dolník, V., Novotny, M., Anal. Chem. 1990, 62, 2478-2483.

[73] Gilges, M., Kleemiss, M. H., Schomburg, G., Anal. Chem. 1994, 66, 2038-2046.

[74] Gao, L., Liu, S., Anal. Chem. 2004, 76, 7179-7186.

[75] Liu, S., Gao, L., Pu, Q., Lu, J. J., Wang, X., J. Proteome Res. 2006, 5, 323-329.

[76] Baryla, N. E., Lucy, C. A., Anal. Chem. 2000, 72, 2280 2284.

[77] Wei, W., Ju, H., Electrophoresis 2005, 26, 586-592.

[78] Lindén, M. V., Wiedmer, S. K., Hakala, R. M. S., Riekkola, M.-L., J. Chromatogr. A 2004, 1051, 61-68.

[79] Pontoglio, A., Viganò, A., Sebastiano, R., Citterio, A. et al., Electrophoresis 2004, 25, 1065-1070.

[80] Doherty, E. A. S., Meagher, R. J., Albarghouthi, M. N., Barron, A. E., Electrophoresis 2003, 24, 34-54.

[81] Cunliffe, J. M., Baryla, N. E., Lucy, C. A., Anal. Chem. 2002, $74,776-783$.

[82] Zhang, H., Yeung, K. K.-C., Anal. Chem. 2004, 76, 68146818.

[83] Yassine, M. M., Lucy, C. A., Anal. Chem. 2004, 76, $2983-$ 2990.

[84] Chen, J., Balgley, B. M., DeVoe, D. L., Lee, C. S., Anal. Chem. 2003, 75, 3145-3152.

[85] Zhang, J., Horváth, C., Electrophoresis 2003, 24, 115-120.

[86] Mohabbati, S., Hjertén, S., Westerlund, D., J. Chromatogr. A 2004, 1053, 201-216.

[87] Graf, M., Garía, R. G., Wätzig, H., Electrophoresis 2005, 26, 2409-2417.

[88] Belder, D., Deege, A., Husmann, H., Kohler, F., Ludwig, M., Electrophoresis 2001, 22, 3813-3818.

[89] Blanco, D., Herrero, I., Laviana, L., Gutiérrez, M. D., J. Liq. Chromatogr. Relat. Technol. 2002, 25, 1171-1185.

[90] Chiou, S.-H., Huang, M.-F, Chang, H.-T., Electrophoresis 2004, 25, 2186-2192.

[91] Huang, M.-F., Kuo, Y.-C., Huang, C.-C., Chang, H.-T., Anal. Chem. 2004, 76, 192-196.

[92] Huang, M.-F., Huang, C.-C., Chang, H.-T., Electrophoresis 2003, 24, 2896-2902.

[93] Vayaboury, W., Kirby, D., Giani, O., Cottet, H., Electrophoresis 2005, 26, 2187-2197.

[94] Chang, W. W. P., Hobson, C., Bomberger, D. C., Schneider, L. V., Electrophoresis 2005, 26, 2179-2186.

[95] Rodriguez, I., Li, S. F. Y., Anal. Chim. Acta 1999, 383, 1-26.

[96] Liu, C. Y., Electrophoresis 2001, 22, 612-628.

[97] Horvath, J., Dolník, V., Electrophoresis 2001, 22, 644-655.

[98] Righetti, P. G., Gelfi, C., Sebastiano, R., Citterio, A., J. Chromatogr. A 2004, 1053, 15-26.

[99] Dolník, V., Electrophoresis 1997, 18, 2353-2361.

[100] Dolník, V., Electrophoresis 1999, 20, 3106-3115.

[101] Luraschi, P., Infusino, I., Merlotti, C., Franzini, C., Clin. Chim. Acta 2004, 349, 151-156.

[102] Visser, N. F. C., van Harmelen, M., Lingeman, H., Irth, H., J. Pharm. Biomed. Anal. 2003, 33, 451-462.

[103] Duly, E. B., Grimason, S., Grimason, P., Barnes, G., Trinick, T. R., J. Clin. Pathol. 2003, 56, 780-781. 
[104] Kaiser, T., Hermann, A., Kielstein, J. T., Wittke, S. et al., J. Chromatogr. A 2003, 1013, 157-171.

[105] Weissinger, E. M., Kaiser, T., Meert, N., De Smet, R. et al., Nephrol. Dial. Transplant. 2004, 19, 3068-3077.

[106] Larsson, A., Hansson, L.-O., Clin. Chem. Lab. Med. 2004, 42, 1396-1400.

[107] Nam, H.-S., Ban, E., Yoo, E., Yoo, Y. S., J. Chromatogr. A 2002, 976, 79-85.

[108] Li, N., Cook, L., Santos, C., Cass, C. E. et al., Anal. Chem. 2002, 74, 2573-2577.

[109] Huang, Y.-F., Hunag, C.-C., Chang, H.-T., Langmuir 2003, 19, 7498-7502.

[110] Wittke, S., Fliser, D., Haubitz, M., Bartel, S. et al., J. Chromatogr. A 2003, 1013, 173-181.

[111] Neuhoff, N. V., Kaiser, T., Wittke, S., Krebs, R. et al., Rapid Commun. Mass Spectrom. 2004, 18, 149-156.

[112] Kaiser, T., Kamal, H., Rank, A., Kolb, H.-J. et al., Blood 2004, 104, 340-349.

[113] Moini, M., Huang, H., Electrophoresis 2004, 25, 19811987.

[114] Sei, K., Nakano, M., Kinoshita, M., Masuko, T., Kakehi, K., J. Chromatogr. A 2002, 958, 273-281.

[115] Yoon, S., Han, K.-Y., Nam, H.-S., Nga, L. V., Yoo, Y. S., J. Chromatogr. A 2004, 1056, 237-242.

[116] Hjertén, S., Zhu, M.-D., J. Chromatogr. 1985, 346, 265270.

[117] Hjertén, S., Elenbring, K., Kilár, F., Liao, J. L. et al., J. Chromatogr. 1987, 403, 47-61.

[118] Shen, Y., Xiang, F., Veenstra, T. D., Fung, E. N., Smith, R. D., Anal. Chem. 1999, 71, 5348-5353.

[119] Sugano, M., Hidaka, H., Yamauchi, K., Nakabayashi, T. et al., Electrophoresis 2000, 21, 3016-3019.

[120] Hempe, J. M., Craver, R. D., Electrophoresis 2000, 21, 743-748.

[121] Mario, N., Baudin, B., Aussel, C., Giboudeau, J., Clin. Chem. 1997, 43, 2137-2142.

[122] Barkemeyer, B. M., Hempe, J. M., J. Perinatol. 2000, 20, 355-358.

[123] Hunt, G., Moorhouse, K. G., Chen, A. B., J. Chromatogr. A 1996, 744, 295-301.

[124] Hunt, G., Hotaling, T., Chen, A. B., J. Chromatogr. A 1998, 800, 355-367.

[125] Hiraoka, A., Seiki, K., Oda, H., Eguchi, N. et al., Electrophoresis 2001, 22, 3433-3437.

[126] Manabe, T., Miyamoto, H., Inoue, K., Nakatsu, M., Arai, M., Electrophoresis 1999, 20, 3677-3683.

[127] Hiraoka, A., Tominaga, I., Hori, K., J. Chromatogr. A 2002, 961, 147-153.

[128] Clarke, N. J., Naylor, S., Biomed. Chromatogr. 2002, 16, 287-297.

[129] Chartogne, A., Gaspari, M., Jespersen, S., Buscher, B. et al., Rapid Commun. Mass Spectrom. 2002, 16, 201-207.

[130] Crowley, T. A., Hayes, M. A., Proteomics 2005, 5, 37983804.

[131] Tang, S., Nesta, D. P., Maneri, L. R., Anumula, K. R., J. Pharm. Biomed. Anal. 1999, 19, 569-583.

[132] Pantazaki, A., Taverna, M., Vidal-Madjar, C., Anal. Chim. Acta 1999, 383, 137-156.

[133] Shimura, K., Hoshino, M., Kamiya, K.-I., Katoh, K. et al., Electrophoresis 2002, 23, 909-917.

[134] Janini, G., Saptharishi, N., Waselus, M., Soman, G., Electrophoresis 2002, 23, 1605-1611.
[135] Hille, J. M., Freed, A. L., Wätzig, H., Electrophoresis 2001, 22, 4035-4052.

[136] Shen, Y., Berger, S. J., Smith, R. D., J. Chromatogr. A 2001 914, 257-264.

[137] Moini, M., Anal. Bioanal. Chem. 2002, 373, 466-480.

[138] Shimura, K., Electrophoresis 2002, 23, 3847-3857.

[139] Manabe, T., J. Chromatogr. B 2003, 787, 29-41.

[140] Storms, H., van der Heijden, R., Tjaden, U. R., van der Greef, J., J. Chromatogr. B 2005, 824, 189-200.

[141] Tang, Q., Harrata, A. K., Lee, C. S., Anal. Chem. 1995, 67, 3515-3519.

[142] Yang, L., Lee, C. S., Hofstadler, S. A., Smith, R. D., Anal. Chem. 1998, 70, 4945-4950.

[143] Martinović, S., Veenstra, T. D., Anderson, G. A., Paša-Tolić, L., Smith, R. D., J. Mass Spectrom. 2002, 37, 99-107.

[144] Hjertén, S., J. Chromatogr. 1983, 270, 1-6.

[145] Cohen, A. S., Karger, B. L., J. Chromatogr. 1987, 397, 409417.

[146] Gomis, D. B., Junco, S., Expósito, Y., Gutiérrez, M. D., Electrophoresis 2003, 24, 1391-1396.

[147] Ganzler, K., Greve, K. S., Cohen, A. S., Karger, B. L., Anal. Chem. 1992, 64, 2665-2671.

[148] Tseng, W.-L., Chang, H.-T., J. Chromatogr. A 2001, 924, 93-101.

[149] Hu, S., Zhang, L., Cook, L. M., Dovichi, N. J., Electrophoresis 2001, 22, 3677-3682.

[150] Hu, S., Zhang, Z., Cook, L. M., Carpenter, E. J., Dovichi, N. J., J. Chromatogr. A 2000, 894, 291-296.

[151] Luo, S., Feng, J., Pang, H.-M., J. Chromatogr. A 2004, 1051, 131-134.

[152] He, Y., Yeung, E. S., J. Proteome Res. 2002, 1, 273-277.

[153] Lu, J. J., Liu, S., Pu, Q., J. Proteome Res. 2005, 4, $1012-$ 1016.

[154] Reynolds, J. A., Tanford, C., J. Biol. Chem. 1970, 245, $5161-5165$

[155] Tseng, W.-L., Chang, H.-T., Anal. Chem. 2000, 72, 48054811.

[156] Tseng, W.-L., Lin, Y.-W., Chang, H.-T., Anal. Chem. 2002, $74,4828-4834$

[157] Pretorius, V., Hopkins, B. J., Schieke, J. D., J. Chromatogr. 1974, 99, 23-30.

[158] Jorgenson, J. W., Lukacs, K. D., J. Chromatogr. 1981, 218 , 209-216.

[159] Knox, J. H., Grant, I. H., Chromatographia 1987, 24, 135143.

[160] Li, Y., Xiang, R., Wilkins, J. A., Horváth, C., Electrophoresis 2004, 25, 2242-2256.

[161] Mistry, K., Grinberg, N., J. Liq. Chromatogr. Relat. Technol. 2004, 27, 1179-1202.

[162] Galceran, M. T., Puignou, L., Trends Anal. Chem. 2005, 24, 743-758.

[163] Lynen, F., Buica, A., de Villiers, A., Crouch, A., Sandra, P., J. Sep. Sci. 2005, 28, 1539-1549.

[164] Steiner, F., Scherer, B., Electrophoresis 2005, 26, 19962004.

[165] Wu, J.-T., Huang, P., Li, M. X., Lubman, D. M., Anal. Chem. 1997, 69, 2908-2913.

[166] Zhang, K., Gao, R., Jiang, Z., Yao, C. et al., J. Sep. Sci. 2003, 26, 1389-1394.

[167] Liang, Z., Duan, J., Zhang, L., Zhang, W. et al., Anal. Chem. 2004, 76, 6935-6940.

[168] Liang, Z., Zhang, L., Duan, J., Yan, C. et al., Electrophoresis 2005, 26, 1398-1405. 
[169] Preinerstorfer, B., Lindner, W., Lämmerhofer, M., Electrophoresis 2005, 26, 2005-2018.

[170] Fu, H., Xie, C., Xiao., H., Dong, J. et al., J. Chromatogr. A 2004, 1044, 237-244.

[171] Palm, A., Novotny, M. V., Anal. Chem. 1997, 69, 44994507.

[172] Ericson, C., Hjertén, S., Anal. Chem. 1999, 71, 1621-1627.

[173] Zhang, S., Zhang, J., Horváth, C., J. Chromatogr. A 2001, 914, 189-200.

[174] Bedair, M., El Rassi, Z., J. Chromatogr. A 2003, 1013, 4756.

[175] Li, Y., Xiang, R., Horváth, C., Wilkins, J. A., Electrophoresis 2004, 25, 545-553.

[176] Matyska, M. T., Pesek, J. J., Boysen, I., Hearn, T. W., Electrophoresis 2001, 22, 2620-2628.

[177] Guihen, E., Glennon, J. D., J. Chromatogr. A 2004, 1044, 67-81.

[178] Kapnissi-Christodoulou, C. P., Zhu, X., Warner, I. M., Electrophoresis 2003, 24, 3917-3934.

[179] Matyska, M. T., Pesek, J. J., Katrekar, A., Anal. Chem. 1999, 71, 5508-5514.

[180] Rehder-Silinski, M. A., McGown, L. B., J. Chromatogr. A 2003, 1008, 233-245.

[181] Gayton-Ely, M., Pappas, T. J., Holland, L. A., Anal. Bioanal. Chem. 2005, 382, 570-580.

[182] Schou, C., Heegaard, N. H. H., Electrophoresis 2006, 27, 44-59.

[183] Bertucci, C., Bartolini, M., Gotti, R., Andrisano, V., J. Chromatogr. B 2003, 797, 111-129.

[184] Østergaard, J., Heegaard, N. H. H., Electrophoresis 2003, 24, 2903-2913.

[185] Guzman, N. A., Stubbs, R. J., Electrophoresis 2001, 22 , 3602-3628.

[186] Guzman, N. A., Anal. Bioanal. Chem. 2004, 378, 37-39.

[187] Phillips, T. M., Smith, P., Biomed. Chromatogr. 2003, 17, 182-187.

[188] Guzman, N. A., Electrophoresis 2003, 24, 3718-3727.

[189] Belenky, A., Hughes, D., Korneev, A., Dunayevskiy, Y., J. Chromatogr. A 2004, 1053, 247-251.

[190] Phillips, T. M., Anal. Chim. Acta 1998, 372, 209-218.

[191] Bornemann, C., Burggraef, T., Heimbüchel, G., Hanisch, F.G., Winkels, S., Anal. Bioanal. Chem. 2003, 376, 10741080.

[192] Jameson, E. E., Cunliffe, J. M., Neubig, R. R., Sunahara, R. K., Kennedy, R. T., Anal. Chem. 2003, 75, 4297-4304.

[193] McEwen, D. P., Gee, K. R., Kang, H. C., Neubig, R. R., Anal. Biochem. 2001, 291, 109-117.

[194] Vo, T. U., McGown, L. B., Electrophoresis 2004, 25, 12301236.

[195] Bock, L. C., Griffin, L. C., Latham, J. A., Vermaas, E. H., Toole, J. J., Nature 1992, 355, 564-566.

[196] Mendonsa, S. D., Bowser, M. T., J. Am. Chem. Soc. 2005, 127, 9382-9383.

[197] Mendonsa, S. D., Bowser, M. T., Anal. Chem. 2004, 76, 5387-5392

[198] Berezovski, M., Drabovich, A., Krylova, S. M., Musheev, M. et al., J. Am. Chem. Soc. 2005, 127, 3165-3171.

[199] Huang, C.-C., Cao, Z., Chang, H.-T., Tan, W., Anal. Chem. 2004, 76, 6973-6981.

[200] Berezovski, M., Nutiu, R., Li, Y., Krylov, S. N., Anal. Chem. 2003, 75, 1382-1386.

[201] Krylova, S. M., Musheev, M., Nutiu, R., Li, Y. et al., FEBS Lett. 2005, 579, 1371-1375.
[202] Drabovich, A., Krylov, S. N., J. Chromatogr. A 2004, 1051, 171-175.

[203] Heegaard, N. H. H., Jørgensen, T. J. D., Rozlosnik, N., Corlin, D. B. et al., Biochemistry 2005, 44, 4397-4407.

[204] Xu, H., Yu, X.-D., Chen, H.-Y., J. Chromatogr. A 2004, 1055, 209-214.

[205] Gudiksen, K. L., Urbach, A. R., Gitlin, I., Yang, J. et al., Anal. Chem. 2004, 76, 7151-7161.

[206] Stroink, T., Paarlberg, E., Waterval, J. C. M., Bult, A., Underberg, W. J. M., Electrophoresis 2001, 22, 2374-2383.

[207] Sentellas, S., Puignou, L., Galceran, M. T., J. Sep. Sci. 2002, 25, 975-987.

[208] Chen, J., Gao, J., Lee, C. S., J. Proteome Res. 2003, 2, 249-254.

[209] Vreeland, W. N., Williams, S. J., Barron, A. E., Sassi, A. P., Anal. Chem. 2003, 75, 3059-3065.

[210] Osbourn, D. M., Weiss, D. J., Lunte, C. E., Electrophoresis 2000, 21, 2768-2779.

[211] Britz-McKibbin, P., Terabe, S., J. Chromatogr. A 2003, 1000, 917-934.

[212] Kim, J.-B., Terabe, S., J. Pharm. Biomed. Anal. 2003, 30, 1625-1643.

[213] Urbánek, M., Křivánková, L., Boček, P., Electrophoresis 2003, 24, 466-485.

[214] Chien, R.-L., Electrophoresis 2003, 24, 486-497.

[215] Chun, M.-S., Kang, D., Kim, Y., Chung, D., Microchem. J. 2001, 70, 247-253.

[216] Ross, D., Locascio, L. E., Anal. Chem. 2002, 74, 25562564.

[217] Wang, S.-J., Tseng, W.-L., Lin, Y.-W., Chang, H.-T., J. Chromatogr. A 2002, 979, 261-270.

[218] Nesbitt, C. A., Lo, J. T.-M., Yeung, K. K.-C., J. Chromatogr. A 2005, 1073, 175-180.

[219] Chiu, T.-C., Lin, Y.-W., Huang, C.-C., Chrambach, A., Chang, H.-T., Electrophoresis 2003, 24, 1730-1736.

[220] Huang, Y.-F., Hsieh, M.-M., Tseng, W.-L., Chang, H.-T., J. Proteome Res. 2006, 5, 429-436.

[221] Mohan, D., Paša-Tolić, L., Masselon, C. D., Tolić, N. et al., Anal. Chem. 2003, 75, 4432-4440.

[222] Wainright, A., Williams, S. J., Ciambrone, G., Xue, Q. et al., J. Chromaotgr. A 2002, 979, 69-80.

[223] Huang, H., Xu, F., Dai, Z., Lin, B., Electrophoresis 2005, 26 , $2254-2260$

[224] Smith, R. D., Loo, J. A., Barinaga, C. J., Edmonds, C. G., Udseth, H. R., J. Chromatogr. 1989, 480, 211-232.

[225] Peterson, Z. D., Bowerbank, C. R., Collins, D. C., Graves, S. W., Lee, M. L., J. Chromatogr. A 2003, 992, 169-179.

[226] Stutz, H., Bordin, G., Rodriguez, A. R., Electrophoresis 2004, 25, 1071-1089.

[227] Xu, Z., Ando, T., Nishine, T., Arai, A., Hirokawa, T., Electrophoresis 2003, 24, 3821-3827.

[228] Dalluge, J. J., Sander, L. C., Anal. Chem. 1998, 70, 53395343.

[229] Saito, Y., Jinno, K., Anal. Bioanal. Chem. 2002, 373, 325331.

[230] Quirino, J. P., Dulay, M. T., Zare, R. N., Anal. Chem. 2001, 73, 5557-5563.

[231] Yu, C., Davey, M. H., Svec, F., Fréchet, J. M. J., Anal. Chem. 2001, 73, 5088-5096.

[232] Oguri, S., Tanagaki, H., Hamaya, M., Kato, M., Toyo'oka, T., Anal. Chem. 2003, 75, 5240-5245.

[233] Liu, Z., Pawliszyn, J., Anal. Chem. 2005, 77, 165-171. 
[234] Bushey, M. M., Jorgenson, J. M., Anal. Chem. 1990, 62, 161-167.

[235] Bushey, M. M., Jorgenson, J. M., J. Microcol. Sep. 1990, 2 , 293-299.

[236] Larmann, J. P., Jr., Lemmo, A. V., Moore, A. W., Jr., Jorgenson, J. W., Electrophoresis 1993, 14, 439-447.

[237] Moore, A. W., Jr., Jorgenson, J. W., Anal. Chem. 1995, 67, 3448-3455.

[238] Hooker, T. F., Jorgenson, J. W., Anal. Chem. 1997, 69, 4134-4142.

[239] Lemmo, A. V., Jorgenson, J. W., Anal. Chem. 1993, 65, 1576-1581.

[240] Tragas, C., Pawliszyn, J., Electrophoresis 2000, 21, 227237.

[241] Zhang, X., Hu, H.-L., Xu, S., Yang, X., Zhang, J., J. Sep. Sci. 2001, 24, 385-391.

[242] Stroink, T., Wiese, G., Teeuwsen, J., Lingeman, H. et al., Electrophoresis 2003, 24, 897-903.

[243] Anderson, N. L., Anderson, N. G., Mol. Cell. Proteomics 2002, 1, 845-867.

[244] Petricoin, E. F. III, Ardekani, A. M., Hitt, B. A., Levine, P. J. et al., Lancet 2002, 359, 572-577.

[245] Adam, B.-L., Qu, Y., Davis, J. W., Ward, M. D. et al., Cancer Res. 2002, 62, 3609-3614.

[246] Petricoin, E. F. III, Ornstein, D. K., Paweletz, C. P., Ardekani, A. et al., J. Natl. Cancer Inst. 2002, 94, 1576-1578.

[247] Li, J., Zhang, Z., Rosenzweig, J., Wang, Y. Y., Chan, D. W., Clin. Chem. 2002, 48, 1296-1304.

[248] Janini, G. M., Chan, K. C., Conrads, T. P., Issaq, H. J., Veenstra, T. D., Electrophoresis 2004, 25, 1973-1980.

[249] Mao, Y., Zhang, X., Electrophoresis 2003, 24, 3289-3295.

[250] Mao, Y., Li, Y., Zhang, X., Proteomics 2006, 6, 420-426.

[251] Milhorat, T. H., in: Wood, J. H. (Ed.), Neurobiology of Cerebrospinal Fluid, Plenum, New York 1983, Vol. 2.

[252] McArthur, J., Hill, J., Paech, M. J., Dodd, P. H. et al., Anaesthesia 2005, 60, 163-167.

[253] Sjögren, M., Andreasen, N., Blennow, K., Clin. Chim. Acta 2003, 332, 1-10.

[254] Verbeek, M. M., de Jong, D., Kremer, H. P. H., Ann. Clin. Biochem. 2003, 40, 25-40.

[255] Betz, A. L., Goldstein, G. W., Katzman, R., in: Siegel, G. J. (Ed.), Basic Neurochemistry, Molecular, Cellular and Medical Aspects, 5th Edn., Raven Press, New York 1994, pp. 681-691.
[256] Stroink, T., Schravendijk, P., Wiese, G., Teeuwsen, J. et al., Electrophoresis 2003, 24, 1126-1134.

[257] Rasmussen, R. K., Ji, H., Eddes, J. S., Zugaro, L. M. et al., Electrophoresis 1998, 19, 818-825.

[258] Tragas, C., Pawliszyn, J., Electrophoresis 2000, 21, 227237.

[259] Chen, J., Lee, C. S., Shen, Y., Smith, R. D., Baehrecke, E. H., Electrophoresis 2002, 23, 3143-3148.

[260] Han, D. K., Eng, J., Zhou, H., Aebersold, R., Nat. Biotechnol. 2001, 19, 946-951.

[261] Wolters, D. A., Washburn, M. P., Yates, J. R. III, Anal. Chem. 2001, 73, 5683-5690.

[262] Kachman, M. T., Wang, H., Schwartz, D. R., Cho, K. R., Lubman, D. M., Anal. Chem. 2002, 74, 1779-1791.

[263] Gygi, S. P., Rist, B., Griffin, T. J., Eng, J., Aebersold, R., J. Proteome Res. 2002, 1, 47-54.

[264] VerBerkmoes, N. C., Bundy, J. L., Hauser, L., Asano, K. G. et al., J. Proteome Res. 2002, 1, 239-252.

[265] Wang, Y., Rudnick, P. A., Evans, E. L., Li, J. et al., Anal. Chem. 2005, 77, 6549-6556.

[266] Zhu, K., Kim, J., Yoo, C., Miller, F. R., Lubman, D. M., Anal. Chem. 2003, 75, 6209-6217.

[267] Zhou, F., Johnston, M. V., Anal. Chem. 2004, 76, 27342740.

[268] Bowerbank, C. R., Lee, M. L., J. Microcol. Sep. 2001, 13, 361-370.

[269] Kvasnička, F., Electrophoresis 2003, 24, 860-864.

[270] Yang, C., Zhang, L., Liu, H., Zhang, W., Zhang, Y., J. Chromatogr. A 2003, 1018, 97-103.

[271] Yang, C., Liu, H., Yang, Q., Zhang, L. et al., Anal. Chem. 2003, 75, 215-218.

[272] Liu, H., Zhang, L., Zhu, G., Zhang, W., Zhang, Y., Anal. Chem. 2004, 76, 6506-6512.

[273] Mohan, D., Lee, C. S., Electrophoresis 2002, 23, 31603167.

[274] Sheng, L., Pawliszyn, J., Analyst 2002, 127, 1159-1163.

[275] Michels, D. A., Hu, S., Schoenherr, R. M., Eggertson, M. J., Dovichi, N. J., Mol. Cell. Proteomics 2002, 1, 69-74.

[276] Hu, S., Michels, D. A., Fazal, M. A., Ratisoontorn, C. et al., Anal. Chem. 2004, 76, 4044-4049.

[277] Michels, D. A., Hu, S., Dambrowitz, K. A., Eggertson, M. J. et al., Electrophoresis 2004, 25, 3098-3105. 